Review

\title{
Evaluating the Transition Towards Post-Carbon Cities: A Literature Review
}

\author{
Marta Bottero (D), Federico Dell'Anna (D) and Vito Morgese*
}

check for updates

Citation: Bottero, M.; Dell'Anna, F.; Morgese, V. Evaluating the Transition Towards Post-Carbon Cities: A Literature Review. Sustainability 2021, 13, 567. https://doi.org/10.3390/ su13020567

Received: 13 December 2020

Accepted: 1 January 2021

Published: 8 January 2021

Publisher's Note: MDPI stays neutral with regard to jurisdictional clai$\mathrm{ms}$ in published maps and institutional affiliations.

Copyright: (C) 2021 by the authors. Licensee MDPI, Basel, Switzerland. This article is an open access article distributed under the terms and conditions of the Creative Commons Attribution (CC BY) license (https:// creativecommons.org/licenses/by/ $4.0 /)$.
Interuniversity Department of Regional and Urban Studies and Planning, Politecnico di Torino, 10125 Turin, Italy; marta.bottero@polito.it (M.B.); federico.dellanna@polito.it (F.D.)

* Correspondence: vito.morgese@polito.it

\begin{abstract}
To achieve the new European targets concerning $\mathrm{CO}_{2}$ emission reduction, the concept of a post-carbon city has been promoted, which is focused on low-energy and low-emission buildings provided with intelligent heating and cooling systems, electric and hybrid cars, and better public transport. This paradigm entails the inclusion of aspects not strictly related to energy exploitation but referring to environmental, social, and economic domains, such as improvement in local energy security, people's opinion on different energy solutions, economic co-benefits for private users, environmental externalities, and so on. In this domain, it is of particular importance to provide the decision makers with evaluation tools able to consider the complexity of the impacts, thus leading to the choice of the most sustainable solutions. The paper aims to investigate the scientific literature in the context of evaluation frameworks for supporting decision problems related to the energy transition. The review is carried out through the scientific database SCOPUS. The analysis allows for systematizing the contributions according to the main families of evaluation methodologies, discussing to what extent they can be useful in real-world applications. The paper also proposes emerging trends and innovative research lines in the domain of energy planning and urban management. While the energy transition is an important trend, the analysis showed that few studies were conducted on the evaluation of projects, plans, and policies that aim to reach post-carbon targets. The scales of application refer mainly to global or national levels, while few studies have been developed at the district level. Life cycle thinking techniques, such as life cycle assessment and cost-benefit analysis, were widely used in this research field.
\end{abstract}

Keywords: energy investment; energy policy; economic evaluation; decision support system; life cycle analysis; cost-benefit analysis (CBA); multi-criteria decision analysis (MCDA); life cycle assessment (LCA); life cycle cost (LCC); sensitivity analysis

\section{Introduction}

The new paradigm of the post-carbon city is becoming increasingly developed [1]. This new concept of urban space has led to a significant reconsideration of the fossil fueldependent city system, which aims at defining a new model of the sustainable city [2]. The European Commission defines a post-carbon city as a city characterized by a lowcarbon system, where buildings are characterized by reduced energy consumption and limited production of climate-altering emissions, thanks to intelligent heating and cooling systems. Equally, the transport sector is influenced by this new concept through the use of electric and hybrid cars and a sustainable public transport system that makes cities less polluted. Taking into account all these challenges, the European Commission released a "Roadmap for moving to a competitive low-carbon economy in 2050", in which the way to achieve a low-carbon future is described [3]. The biggest challenges are the refurbishment of existing buildings because, in Europe, new buildings only comprise 1\% of the total amount of building stocks and the expansion of new measures and interventions at the district and municipal level. Furthermore, since the percentage of the global population 
living in the urban context will increase, reaching the percentage of $70 \%$ of people living in cities by 2050, the urban level will become fundamental to develop new sustainable models. In this perspective, all sectors can contribute to reducing emissions, and every possible action must be made from every side. The focus on the energy transition of cities was also underlined by the United Nations in the definition of the 17 Sustainable Development Goals (SDGs) within the 2030 Agenda [4]. Sustainable development to tackle climate change and build peaceful societies by the year 2030 is strongly reiterated by the SDG 11. In particular, the goal is to make cities and human settlements inclusive, safe, and durably built from a sustainable perspective. The main challenge is to keep urban centers as workplaces capable of producing income without damaging the environment and the territory and preserving natural resources by 2030. Energy is the central element of SDG 7, which aims to ensure access to affordable, reliable, sustainable, and modern energy systems for all. SDGs 7 and 11 recognize the close link between cities and the energy sector, with the sole objective of guaranteeing human well-being by reducing energy poverty and preserving the environment by reducing the effects of climate change. Moreover, the goal of climate neutrality was evoked in December 2019 by the European Commission, which placed the environment at the center of its political action and launched the European Green Deal, which aims to base Europe on a green economy that can achieve carbon neutrality by 2050 [5]. The Green New Deal has assumed a leading role, especially during 2020 in the European panorama, passing from a strategy for growth to a strategy for relaunching the economy in the post-COVID-19 period [6].

With innovative and sustainable city models, new parameters come into play, intending to identify the best design profile to respond to new energy, environmental, and market policies. In this sense, evaluation tools able to support Decision Makers (DMs) and stakeholders in decision processes in the domain of the transformation of buildings/cities/regions are needed. A wide variety of tools for organizing and processing energy problems are available. The main evaluation methods could be clustered in three families; economic methods, multi-criteria approaches, and environmental evaluation techniques. Among the monetary methods, the most common standardized approaches used in the domain of energy decision-making problems are life thinking techniques, such as life cycle cost (LCC) [7] and cost-benefit analysis (CBA) [8]. In 2010, the Energy Performance of Buildings Directives recast (EBPD, 2010/31/EU) introduced the cost-optimal approach, which is determined by considering the overall costs related to the useful life of a building, such as investment costs for energy efficiency, costs of maintenance, operation, and replacement, and any disposal costs [9]. Over the past decade, multi-criteria decision analysis (MCDA) techniques have been widely used in this field [10]. These evaluation tools can support the decision problem in different ways and considering different evaluation principles. Unlike CBA, MCDA is inclined to involve decision-makers to capture a wide range of perspectives and verify the power of stakeholders' consent. Hybrid models that combine manual-based CBA with MCDA methods in the field of the district sustainability sector are being developed so that tangible and intangible criteria can be included in the assessment [11-13]. Moreover, several certification protocols based on qualitative assessment have been developed to assess the sustainability of buildings and neighborhoods, up to urban plans. These assessment tools define a project's performance score, analyzing all stages of the life cycle, from raw material purchase to demolition, and including the full range of economic, environmental, and social impacts [14-16]. The most widely used and recognized international certification schemes are the "Building Research Establishment Environmental Assessment Method" (BREEAM) [17], the "Leadership in Energy and Environmental Design" (LEED) [18], the "Green Star" in Australia [19], "Comprehensive Assessment System for Building Environmental Efficiency" (CASBEE) in Japan [20], and the "Green Mark" in Singapore [21].

In the context of the energy transition, review articles are limited. Most of the articles in the literature present in the most well-known and reliable bibliometric databases connect the concept of the energy transition to specific cases. Often, the energy transition is linked 
to the concept of landscape transformation, land consumption, the use of renewable energy sources, and what benefits they bring but also what conflicts they have with the Sustainable Development Goals [22-26]. Papers have also been written about specific methods that can be used to examine the energy transition, such as system dynamics [27]. Other papers argue the issue from a regulatory point of view and how states can overcome the barriers that block a post-carbon vision and the reasons why it is necessary to do so [28,29]. Horschig and Thrän [30] examined several modeling approaches applicable to renewable energy policy planning and evaluation. However, the review is focused on quantitative and qualitative approaches, such as input/output modeling [31], computable general equilibrium modeling [32], system dynamics modeling [33], agent-based modeling [34], theory-based evaluation [35], multiple decision aiding analysis [36], and hybrid approaches. The authors do not take into consideration the monetary approaches that constitute the main tools required by national or international energy directives such as discounted cash flow (DCF), cost-benefit analysis (CBA) [8], and life cycle cost (LCC) [37].

The proposed paper, on the other hand, aims to have a broader view of the concept of energy transition and post-carbon vision. It proposes an innovative literature review that provides a systematic assessment of the energy transition, aiming to demonstrate the importance that the different evaluation methods acquire within the theme and the various fields of application that these methods are involved in. In addition, this review aims to highlight how different evaluation approaches can help to take into consideration the benefits and advantages for the development of society and future generations in a sustainable way $[38,39]$.

This research aims to get a clear point of view on the issue of the energy transition, that is, the shift from the use of non-renewable energy sources to renewable sources. This change of direction is the basis for the formation of sustainable economies that are attentive to the use of renewable energy and sustainable development [40]. The study focuses, in particular, on the geographical areas that have shown a particular interest in this issue, but also the sector in which the topic is inserted, such as buildings, urban infrastructure, or, more generally, that of cities. The research also focuses on analyzing the role of different evaluation methods and approaches to support this goal. To achieve the purpose of the research, the literature analysis was carried out using the SCOPUS database. The paper is structured as follows: after the Introduction, a section dedicated to research methodology describes the method used to conduct the analysis of the literature and the different steps of the investigation. Next, the results section highlights the outcomes of the different steps taken during the analysis. Finally, in the Conclusions, the paper seeks to explain the overall view of the topic covered and the most interesting results present in the literature, but also the key points for future perspectives of the research.

\section{Research Methodology}

As previously mentioned, the purpose of this paper is to develop a bibliography analysis of literature regarding the context of energy transition and post-carbon vision, focusing in particular on decision-making processes and the role of evaluation tools. The aim is to highlight the more recent trends and key topics relevant to this issue, and obtain a current view of decision tools for supporting a sustainable economy and development. This overview can be useful as a guide for future research activities and for proving the central role that evaluation methods can play in this field of interest. The literature's bibliography analysis was conducted using the SCOPUS database, one of the most well-known and reliable online bibliography collection platforms. The analysis and all the data collected for the drafting of this paper are part of the period from May 2020 to October 2020. A multistep approach was used in this research. Figure 1 shows the framework of the literature review performed in this research. The first step was selecting the keywords to use in the SCOPUS search. Specifically, given the large number of documents on the energy topic on SCOPUS, the analysis was conducted on three different and increasingly specific levels, adding keywords to the basic ones chosen to refine the research carried out. For the first 
phase of the search, the most general one, it was decided to use the following keywords: ("evaluation" OR "valuation" OR "assessment") AND ("energy transition" OR "post-carbon"). A total of 14,443 documents were found with an "all fields" search, while 699 documents were found by limiting the search to title, abstract, and keywords. The second phase of the research aimed at limiting the analysis to the territorial scale to which the documents found refer, and subsequently to the sector. For this purpose, specific keywords were added that focus on the scale of the application. The keywords used are the following:

- (("evaluation" OR "valuation" OR "assessment") AND ("energy transition" OR "postcarbon") AND ("global")) = 139 Documents;

- (("evaluation" OR "valuation" OR "assessment") AND ("energy transition" OR "postcarbon") AND ("national")) = 91 Documents;

- (("evaluation" OR "valuation" OR "assessment") AND ("energy transition" OR "postcarbon") AND ("regional")) = 63 Documents;

- (("evaluation" OR "valuation" OR "assessment") AND ("energy transition" OR "postcarbon") AND ("urban")) = 63 Documents;

- (("evaluation" OR "valuation" OR "assessment") AND ("energy transition" OR "postcarbon") AND ("district")) = 23 Documents.

Next, the analysis was narrowed based on the sector they refer to. Specifically, it was chosen to include the building sector, infrastructure sector, and, more generally, the city. The keywords used are the following:

- (("evaluation" OR "valuation" OR "assessment") AND ("energy transition" OR "postcarbon"))) AND ("building") $=86$ Documents;

- (("evaluation" OR "valuation" OR "assessment") AND ("energy transition" OR "postcarbon"))) AND ("infrastructure") $=52$ Documents;

- (("evaluation" OR "valuation" OR "assessment") AND ("energy transition" OR "postcarbon") AND ("city" OR "cities")) $=56$ Documents.

For both searches in this second phase, the analysis was carried out considering only the results by title, abstract, and keywords. In the third phase of the analysis-the most interesting for the research-other keywords were added with the precise purpose of focusing on evaluation methods and approaches to identify, thanks to the analysis of the literature, what are the trends and use of these methods in the topic of energy. The new keywords used were partly suggested by SCOPUS as search filters, while others were manually entered into the database. The words that appeared as suggestions in the filters are the following:

"Life Cycle Assessment (LCA)" (28 document results); "Cost-Benefit Analysis" (22 document results); "Sensitivity Analysis" (16 document results); "Environmental Impact Assessment" (14 document results); "Monte Carlo Methods" (13 document results).

While the manually added words that reference evaluation methods are as follows:

"Discounted Cash Flow" OR "DCF" (0 results); "Life Cycle Cost" OR "LCC" (4 document results); "Multicriteria" OR "MCDA" OR "MCA" OR "Multi-criteria" OR "Multiple Criteria Decision Analysis" (13 Document Results); "Neural network" (2 document results); "Regression Analysis" OR "Parametric Model" (3 document results); "Preference evaluation" OR "econometrics" (5 document results); "Geographical Information System" OR "GIS" (12 document results); "Quantitative Analysis" (15 document results).

Those keywords were added to the string of keywords used in the first analysis phase. In the next paragraphs, these three phases will be named, respectively, Group A, Group B, and Group C. For each group, different analyses were conducted, which are titled historical production analysis, country productivity analysis, and subject area analysis. The first type of analysis (historical production) allows the comprehension of the productivity of the literature relating to these themes in the time frame indexed in SCOPUS. In this way, it is possible to understand the overall trend of the selected sample. The second analysis 
(country productivity) shows how many documents published by the different countries were produced in the period indexed in SCOPUS, according to the authors' affiliation city. The third analysis (subject area) provides an overview of the sectors dealing with the issue of the energy transition and post-carbon issue. In addition, a cross-sectional comparison of the selected keywords for each group was provided to understand the relevance of specific words, approaches, and methods in this field. In particular, this comparison can support the identification of the gaps in literature production and of the most consolidated fields of research.

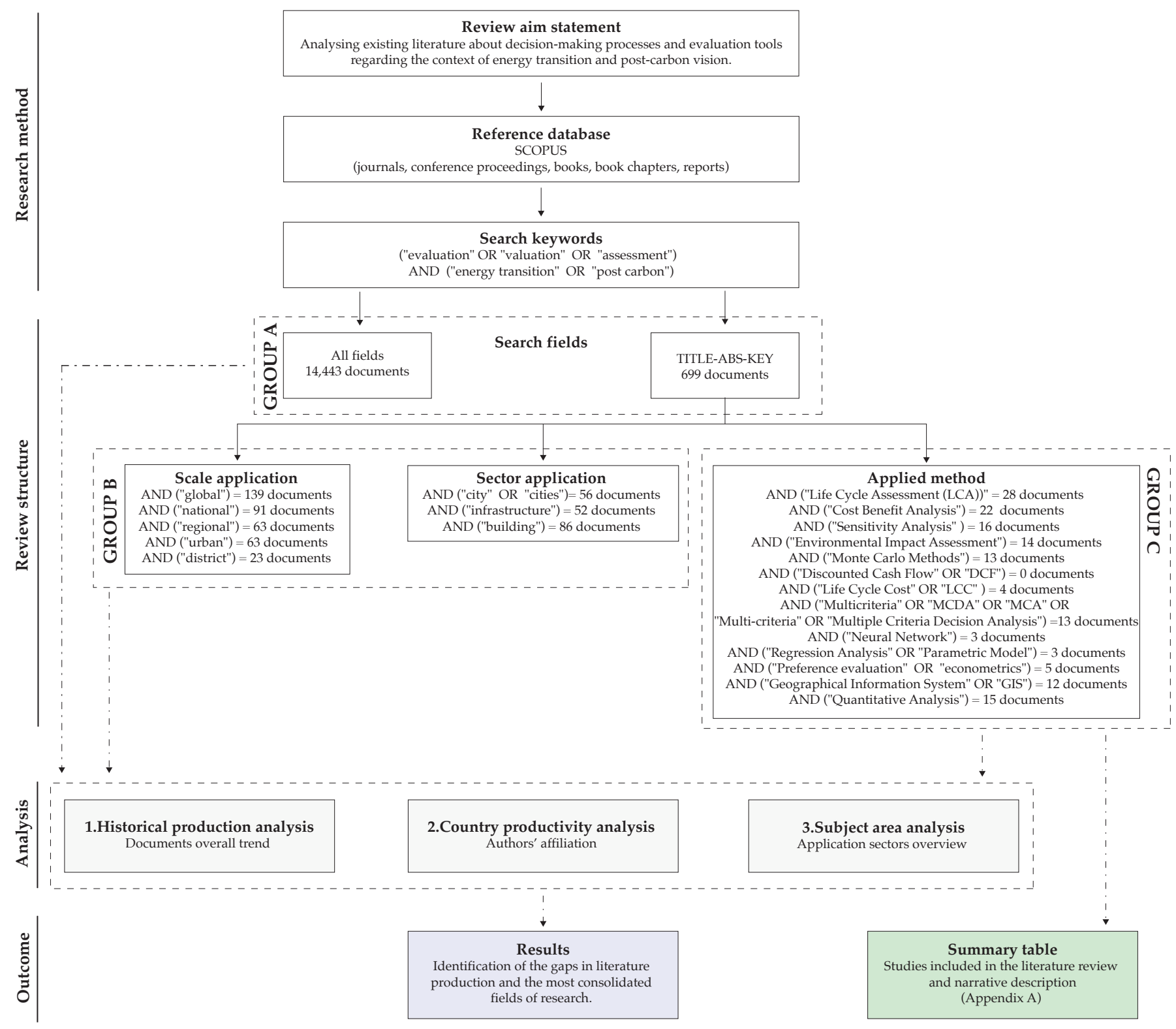

Figure 1. Literature review framework.

\section{Results and Discussion}

\subsection{Group A: Analysis about Search Fields}

The first analysis conducted on the topic of energy and post-carbon transition shows a large number of documents; 14,443 considering all with an "all fields" search, and 699 by limiting the search to title, abstract, and keywords. Historical production started in 1957, but only in the 1980s is the number of indexed documents over 10 per year. The intensive 
production of literature about the energy transition and post-carbon issue began after the 2000s. From 2000 to 2020, the number of documents is 14,138 , equal to $97 \%$ of the entire literature production. In particular, in the last 10 years, the number documents published is 13,359 , which is $92 \%$ of the total. The second analysis, which focused on the research on title, abstract, and keywords (TITLE-ABS-KEY), shows similar results to the historical production. Additionally, in this case, the first document indexed in SCOPUS dates back to 1957, but only in 2005 is there a slight increase in production. From 2010 to 2020, the literature production increases significantly, with a total of 650 documents, equal to $93 \%$ of the entire production. Figure 2 reports the historical production of the literature for the research in "all fields" and limited to title, abstract, and keywords.

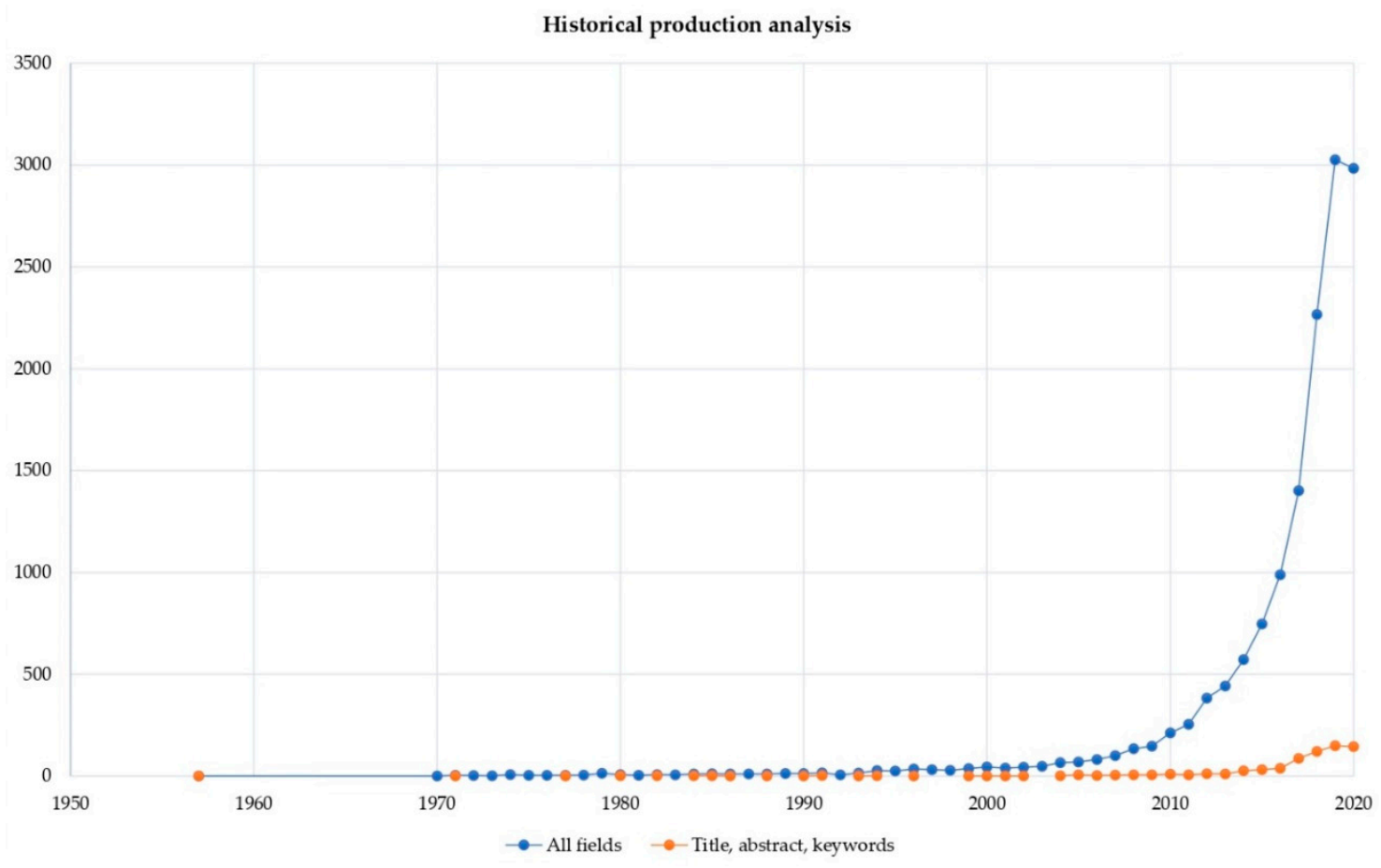

Figure 2. Historical production for "all fields" research and limited to title, abstract, and keywords.

The examination of the subject areas performed by SCOPUS is reported in Figures 3 and 4, and shows how many sectors deal with the topic of energy transition and post-carbon, including from energy to engineering, and from chemistry to mathematics, for a total of 27 subjects. Figure 3 shows the analysis of the 14,443 documents found on SCOPUS, and the main subjects involved in this topic are energy, environmental science, social science, and engineering. These four subjects alone account for $63 \%$ of the entire literature production.

In the same way, Figure 4 shows the analysis of sectors that have included this topic, taking into consideration only the 699 documents found by limiting to title, abstract, and keywords. In this case, energy, environmental science, and engineering represent the subjects with the largest number of documents. Social science is only equal to $9.4 \%$ of the total.

Comparing the weights of the two keywords energy transition and post-carbon, which are the keystones of this literature review, it can be seen that of the 699 documents found in SCOPUS, only 24 documents are related to the post-carbon keyword. Figures 5-8 show the results of the analysis of the comparison between the energy transition and post-carbon keywords. The largest proportion of documents related to energy transition was written in 2020 (172 documents). For the energy transition keyword, the production of literature has increased significantly in the last four years (Figure 5). While the contributions that use the post-carbon keyword record a constant trend, the production starts in 2005 to present, with a narrow difference throughout these fifteen years (Figure 6). Most of the documents 
with the energy transition keyword were involved in the fields of energy, environmental science, and engineering (Figure 7). The sector that used the post-carbon keyword the most is environmental science (Figure 8).

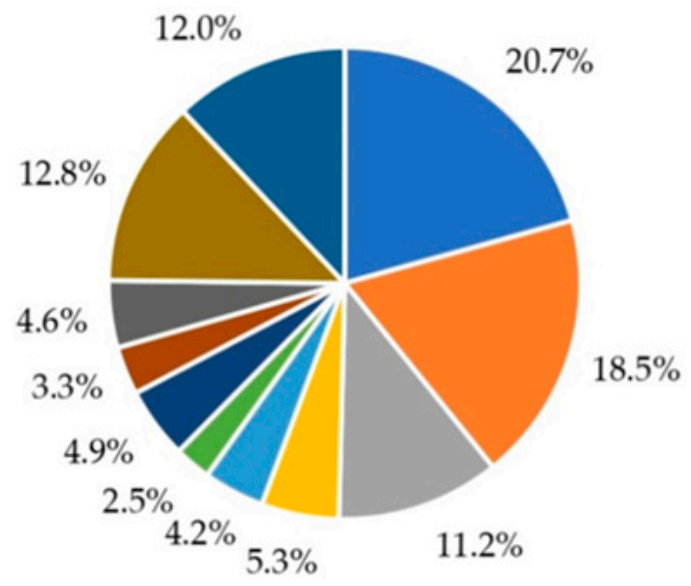

- Energy

= Engineering

- Economics, Econometrics and Finance

- Chemistry

- Physics and Astronomy

- Others
= Environmental Science

= Business, Management and Accounting

- Mathematics

- Earth and Planetary Sciences

- Social Sciences

Figure 3. Subject area analysis for all fields of research.

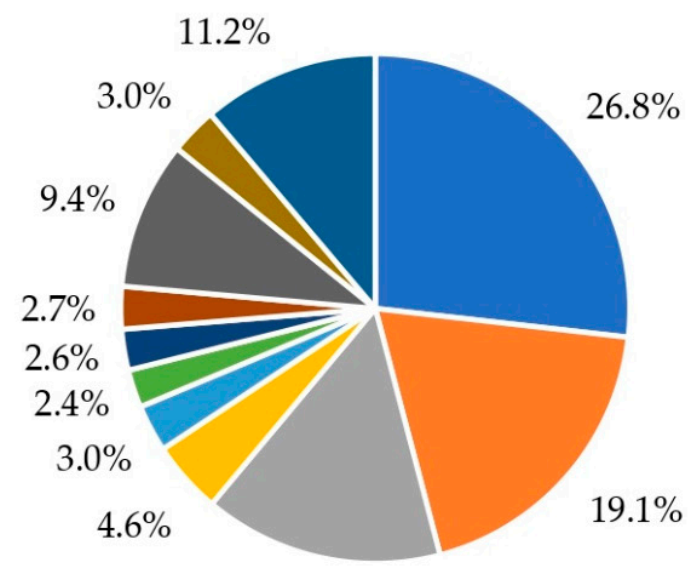

$15.2 \%$

- Energy

- Engineering

- Economics, Econometrics and Finance

- Mathematics

- Social Sciences

- Others
- Environmental Science

- Business, Management and Accounting

- Materials Science

- Physics and Astronomy

- Computer Science

Figure 4. Subject area analysis limited to title, abstract, and keywords. 


\section{Historical production analysis}

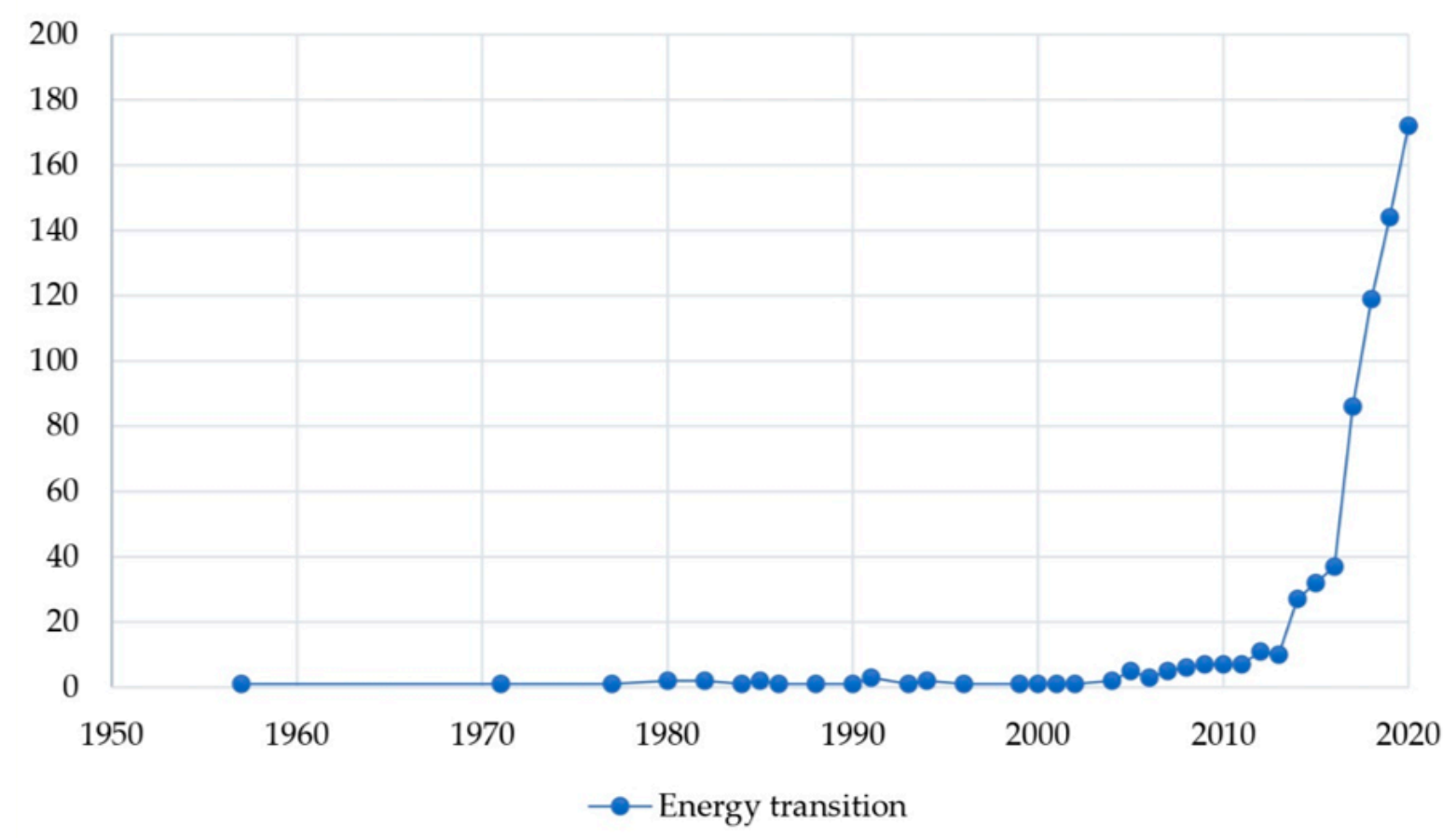

Figure 5. Historical production of literature using "energy transition" keyword in research, limited to title, abstract, and keywords.

Historical production analysis

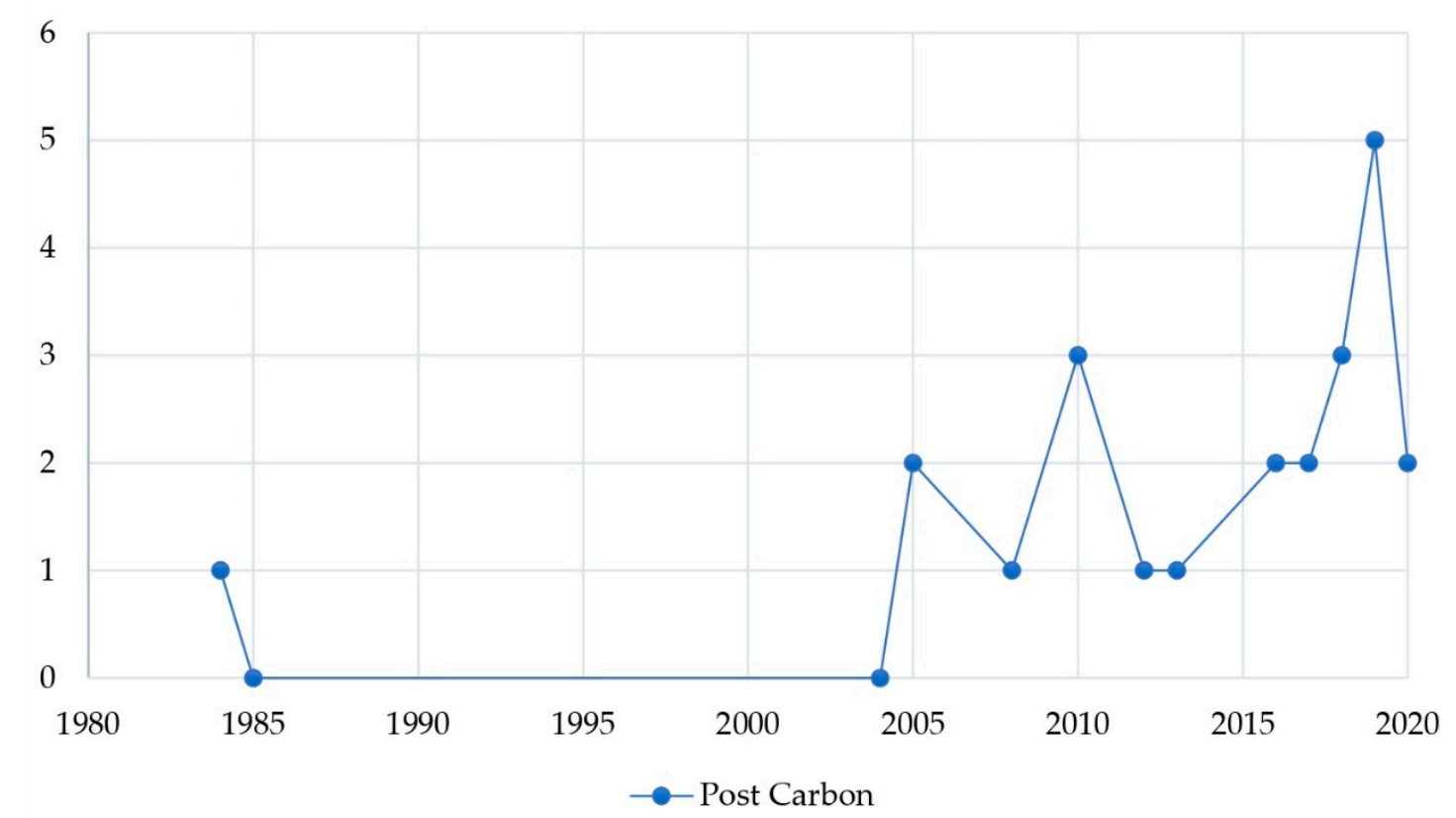

Figure 6. Historical production of literature using "post-carbon" keyword in research, limited to title, abstract, and keywords. 


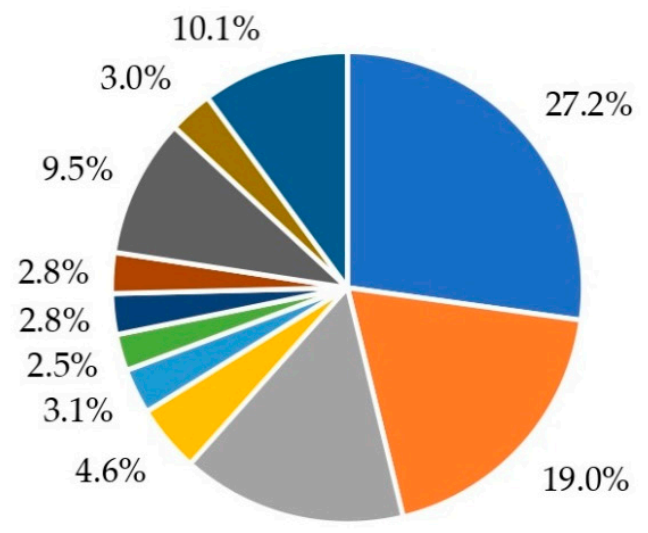

$15.4 \%$

- Energy

- Engineering

- Economics, Econometrics and Finance

- Mathematics

- Social Sciences

- Others
- Environmental Science

* Business, Management and Accounting

- Materials Science

- Physics and Astronomy

- Computer Science

Figure 7. Subject area analysis for articles that used "energy transition" as a keyword.

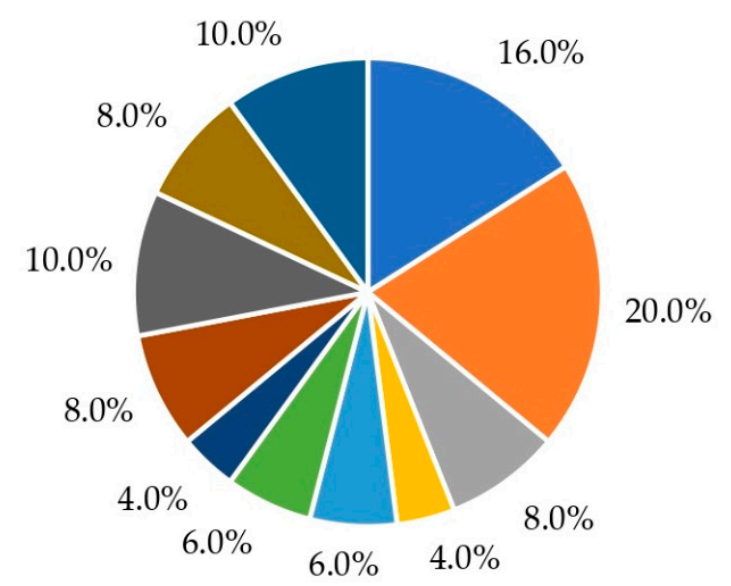

- Energy

Engineering

= Chemical Engineering

- Earth and Planetary Sciences

- Computer Science

- Others
Environmental Science

- Business, Management and Accounting

- Dentistry

- Social Sciences

- Decision Sciences

Figure 8. Subject area analysis for articles which used "post-carbon" as a keyword.

3.2. Group B: Energy Transition and Post-Carbon View at Territorial Scale and in Sector of Application

The second phase of analysis focused on the territorial scale in which the documents are inserted. The searches were conducted by limiting the research to title, abstract, and keywords. In particular, five searches were performed, each one using a specific 
keyword that identifies a particular scale. The keywords used are the following: global, national, regional, urban, district. The results show that the global keyword has the largest number of documents (139 documents). Twenty-three documents are related to the district keyword which addresses the issue on a smaller and less used territorial scale. The historical production for the national keyword has been extensive since the 1970s. For the district keyword, instead, the first documents date back to 2015, with a slight increase in recent years. In each case, about $90 \%$ of documents relating to the different scales were written after 2015. Figure 9 reports the historical trends of literature for the different territorial analyses considered in this study.

\section{Historical production}

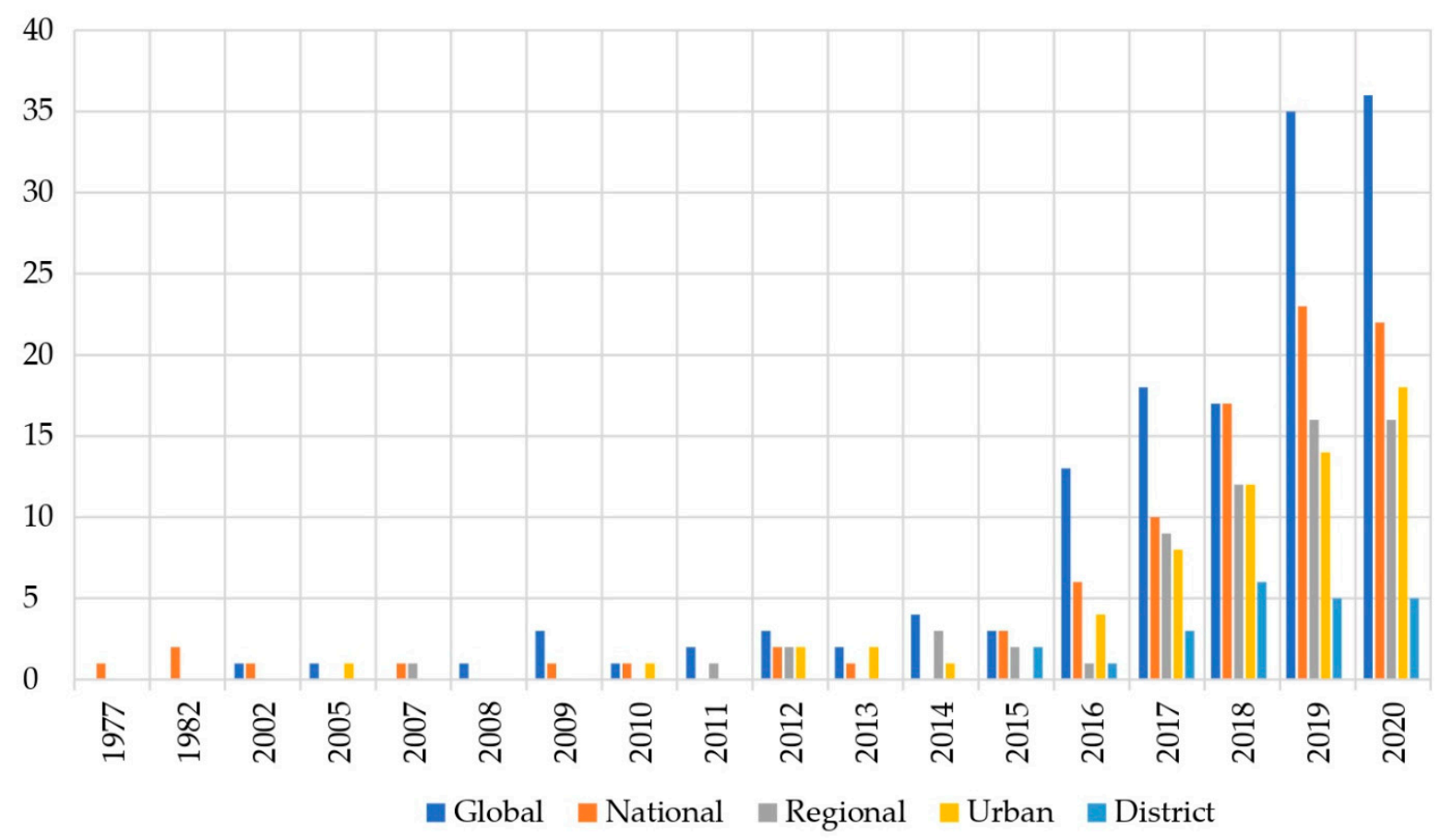

Figure 9. Historical production in different territorial scales.

Finally, as regards country productivity analysis, it is clear that the most of the documents were written in Germany. However, some slight differences can be observed between different countries. For example, with regard to the global territorial scale, the main producing countries are Germany and the United States, with 35 and 21 documents, respectively. On the national territorial scale, the UK is more productive than the United States. It is interesting to note that Italy is, together with Switzerland, the country with the highest production of documents linked to the urban territorial scale. At the same time, Italy and Germany are the countries with the greatest interest in writing documents about the district scale in the field of the energy transition and post-carbon issue. Figure 10 shows the number of publications produced by each country. Those with a lower incidence due to few publications are considered as "Others".

As mentioned above, most of the documents that include the district keyword were written in Germany, Italy, and Spain since 2015. The main subjects of those 23 documents are energy, environmental science, and engineering. Furthermore, taking into consideration the analysis of documents for affiliations carried out by SCOPUS, the results conclude that the Politecnico di Torino is the institution with the highest number of affiliations, followed by the Technical University of Munich [41]. Figure 11 shows the result of the analysis on authors' affiliations performed by SCOPUS. 


\section{Country productivity}

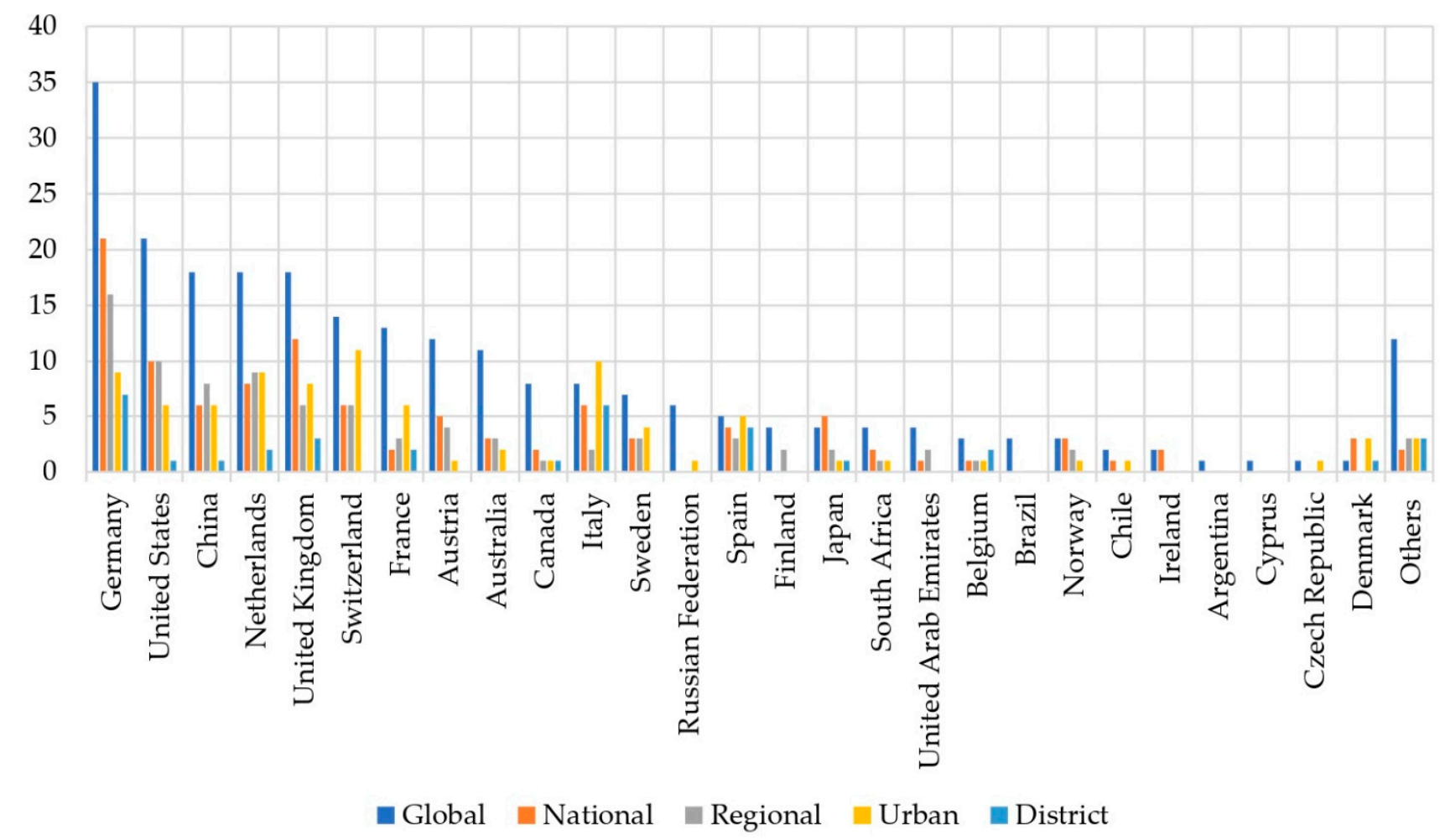

Figure 10. Number of publications per country.

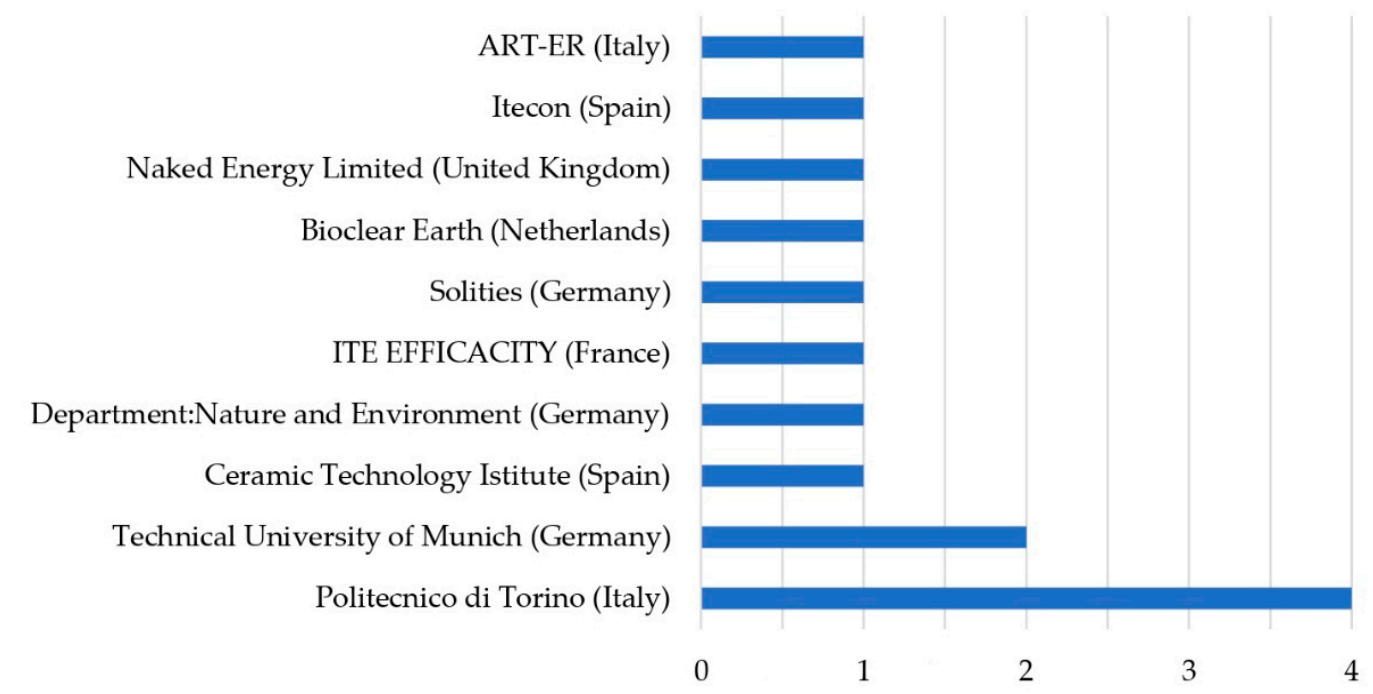

Figure 11. Number of documents by affiliations performed by SCOPUS.

The second search conducted in Group B narrows the analysis of the first group of documents found (699) based on the sector to which they refer. Specifically, three searches were carried out: one for the building sector, one for the infrastructure sector, and the last one, more generally, for the city environment. The results show that 86 documents deal with the building sector, 56 documents with city/cities, and 52 with the infrastructure sector. 


\subsection{Group C: Evaluation Approach and New Trends in Energy Transition and Post-Carbon View}

The purpose of the third analysis-the most interesting for this literature review-is to focus on evaluation approaches, operational research, and new trends emerging about this topic. The search starts from the primary analysis (Group A). New keywords were introduced each time in each search, and in some cases derived from filter keywords suggested by SCOPUS in the primary search. Interestingly, words like life cycle assessment (LCA) and cost-benefit analysis (CBA) are among the first keywords suggested by SCOPUS. Other keywords are defined according to the authors' disciplinary field, to verify the possible gaps present in the literature production and highlight the importance of the specific approach and evaluation methods in the field of energy and post-carbon transition.

The results show different situations, as can be seen in Figure 12 and Table A1 in Appendix A. Discount cash flow (DCF) is absent in the literature production on this topic. On the contrary, LCA is the most used approach for the energy transition and post-carbon issue (28 documents). Another relevant result is given by the adoption of CBA (21 documents). Sensitivity analysis, environmental impact assessment, Monte Carlo methods, MCDA, GIS, and quantitative analysis have approximately the same number of documents, with more than 13 documents each. A greater number of documents with LCA and CBA could be explained by the relation that these methods have with the themes of the energy transition, what benefits come from the use of renewable sources, and the possibility to monitor and reuse each thing done with this type of energy approach [42-50]. Furthermore, LCA and CBA are manual-based analyses mostly used in practice to validate the economic feasibility of a large-scale project $[8,51]$. The absence of documents related to DCF can be partially explained by its use as an ex-ante approach to calculate the feasibility of new constructions or interventions, and is therefore more connected with the economic area.

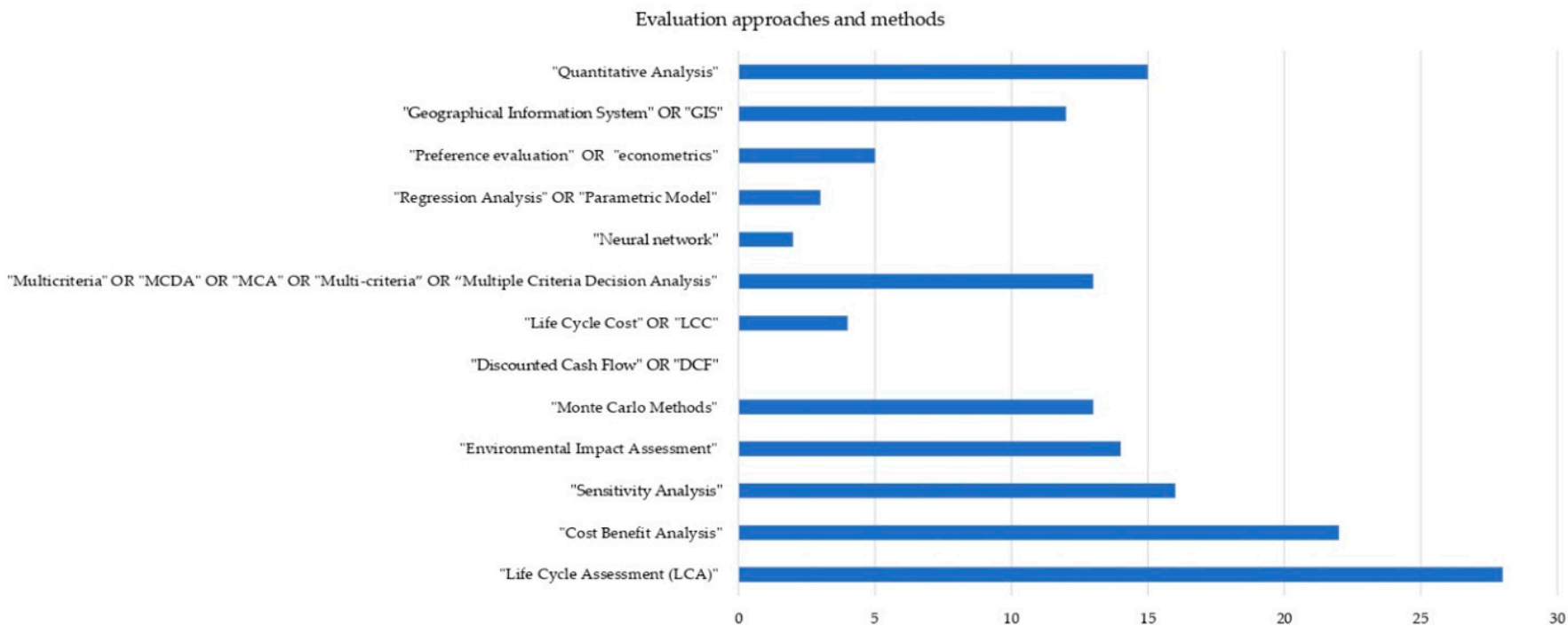

Figure 12. Number of documents in relation to evaluation approaches and methods.

Generally, the historical production in the context of evaluation approaches and methods to support the issue of energy transition and post-carbon target starts around 2005. In the last three years, the intensive production of documents begins, as it is possible to see in Figure 13. Most methods and approaches were involved in the energy sector only in recent years, but there are some exceptions. GIS and neural networks are the first two methods to appear in the articles between 2005 and 2006. However, these evaluation methods reappeared in the searches only in 2014, slightly increasing their presence in documents. Anyway, the increase in these evaluation methods within the documents only in recent years is caused by the modernity of the theme of the energy transition, but also because the evaluation methods are recent and not yet consolidated. As might 
be expected, the results of the subject area analysis show an important production in the fields of energy, environmental science, and engineering in general for all evaluation approaches considered, as can be seen in Figure 14. It is interesting to notice that GIS and environmental impact assessment have the largest number of documents associated with social science, with seven and six documents, respectively.

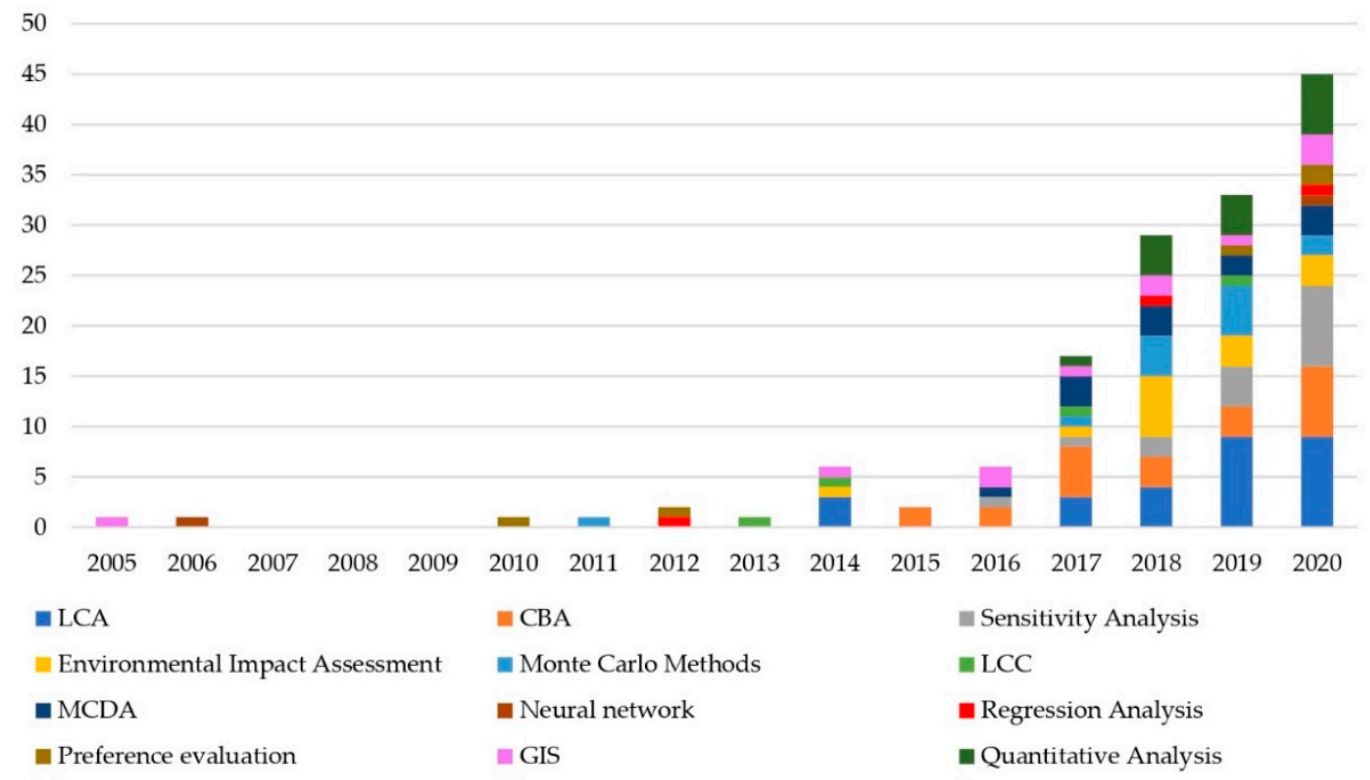

Figure 13. Historical production of literature per evaluation approach and method considered.

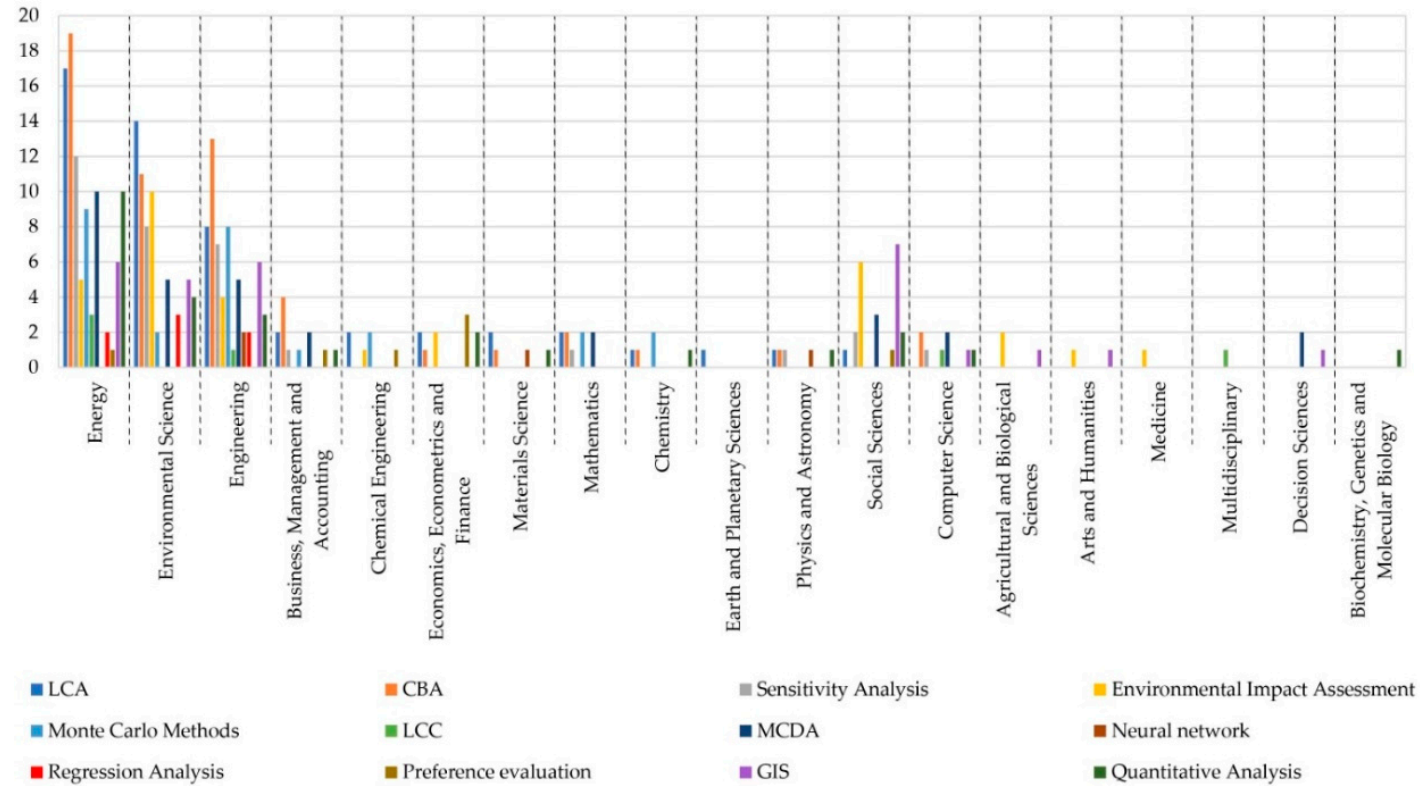

Figure 14. Subject areas per evaluation approach.

\section{Conclusions and Future Implications}

The present paper allowed us to understand the recent trends and the main issues related to the theme of energy transition and post-carbon targets. The energy transition and post-carbon view are currently the main trends because they are closely linked to the concept of sustainable development and the life cycle of products. This relationship 
is also reflected in the recent number of documents adopting LCA and CBA approaches. The application of these two techniques by the academic literature in the energy sector is due to the fact that they represent the tools recognized at the European level in terms of project evaluation for all member states, regulated by standards capable of guaranteeing absolute transparency in the selection of projects to be carried out. In these documents, the topics range from the chemical to the food industry, and from the use of non-renewable resources to new renewable energy models, evaluating the realization costs and benefits brought about by some changes in the production methods.

Another aspect that emerges from this review is the growing interest in the field of energy transition and the natural environment to be preserved, with particular attention paid to the benefits and advantages for the development of society and future generations. These aspects are in fact in line with the aims suggested by the Sustainable Development Goals defined by the United Nations. In this context, life cycle analyses let to consider all the positive and negative impacts generated by a project, allowing us to obtain an overview of the performances and calculate the net benefit for society, and guarantee the achievement of economic and environmental sustainability goals.

It is clear that the interest in this topic involves all the world and will have positive repercussions on the environment on a planetary scale. From the territorial-scale analysis, the interest of different countries to study the impact of energy transition in a global vision is highlighted. The number of documents related to a global scale is greater with respect to the other territorial scales taken into consideration. Nevertheless, the interest in the district scale is deepened in different countries. The idea to operate on a small scale could probably guarantee the application of the post-carbon vision. Creating and making small areas of cities self-sufficient from an energy point of view, with a proactive character regarding the principles of eco-sustainability, are certainly easier. This is the beginning of a necessary change, which allows us to preserve natural resources and ensure a better quality of life for future generations.

It was interesting to discover that Italy, among the various European countries, is more interested in working and developing research on an urban and district scale, studying realistic solutions for cities and promoting their development with the purpose of guaranteeing the best quality of life. As previously mentioned, the Politecnico di Torino is the university with the majority of published documents and a high interest in developing studies in this field.

This preliminary search on SCOPUS has highlighted in recent years an increase in documents on this sector. Particularly interesting was the comparison between historical and country production and the subject areas, as well as the evaluation approaches and methods, to guide and understand the development of new trends in the research and which topics could be explored in the future.

The research provides a comprehensive view of the state of the art, which is useful for guiding future research and demonstrating the role of some evaluation approaches and methods in this field. At the same time, the research certainly shows some limitations. First of all, the analysis was conducted using a single database, even though SCOPUS is one of the most recognized and reliable bibliometric databases. Secondly, the search was implemented in a general way, because there is no in-depth analysis on individual documents, and the search, specifically, in the second and third stages, is limited to title, abstract, and keywords. Thirdly, the analyzed topic is very recent and there are not many applications of the evaluation methods in this area, so there are few documents to conduct an exhaustive analysis. Future investigations could consider the possibility of analyzing the individual documents in a more advanced way, to better understand the role and potentials of the single approach and methods applied in the view of energy changes. Since COP21, with the adoption of the Paris Agreement on Climate, and the new objectives set by the United Nations Economic Commission for Europe (UNECE), an increasing number of cities have committed themselves to concretely combat climate change and to pursue the common goal of carbon neutrality. The $\mathrm{C} 40$ cities established that the neutral city must 
also take into consideration the urban sectors relevant to green spaces, waste, and water, and not only energy, mobility, and buildings, with the general objective of promoting sustainable development and ensuring green growth. In this comprehensive perspective, every single part of the city becomes a potential field of the experiment for new zerocarbon technologies. This vision involves a certain complexity in the definition of decisions. Multi-step evaluation procedures that investigate the economic, environmental, and social performance of city transition operations are necessary to define the milestones for actions in priority areas and create an organizational framework. Furthermore, hybrid models that facilitate dialogue between the different stakeholders involved can help define a decision-making process that is inclusive from a social point of view and sustainable from an economic and environmental point of view. In the future, it will be interesting to understand how the academic sector, researchers and scholars respond to the new rules that will emerge from these new models of sustainable cities and support public and private DMs.

Author Contributions: Conceptualization, M.B., F.D., and V.M.; methodology, M.B., F.D., and V.M.; investigation M.B., F.D., and V.M.; data curation, M.B., F.D., and V.M.; writing-original draft preparation, M.B., F.D., and V.M.; visualization, M.B., F.D., and V.M. All authors have read and agreed to the published version of the manuscript.

Funding: This research received no external funding.

Institutional Review Board Statement: Not applicable.

Informed Consent Statement: Not applicable.

Data Availability Statement: Not applicable.

Conflicts of Interest: The authors declare no conflict of interest.

\section{Appendix A}

Table A1. Summary collection of studies by type of evaluation applied (Group C).

\begin{tabular}{|c|c|c|c|c|}
\hline Authors & Years & Source Title & Evaluation Method & Objective and Application Context \\
\hline Barnes et al. [52] & 2005 & $\begin{array}{l}\text { The Urban Household } \\
\text { Energy Transition: } \\
\text { Social and } \\
\text { Environmental Impacts } \\
\text { in the Developing } \\
\text { World }\end{array}$ & $\begin{array}{l}\text { Geographical } \\
\text { Information System }\end{array}$ & $\begin{array}{l}\text { Analysis of the use of renewable } \\
\text { energy and impacts on society }\end{array}$ \\
\hline $\begin{array}{l}\text { Shterenlikht and } \\
\text { Howard [53] }\end{array}$ & 2006 & $\begin{array}{l}\text { Fatigue and Fracture of } \\
\text { Engineering Materials } \\
\text { and Structures }\end{array}$ & Neural Network & $\begin{array}{l}\text { Evaluation of the ductile to brittle } \\
\text { transition behavior of ferritic steels. }\end{array}$ \\
\hline Duke et al. [54] & 2010 & $\begin{array}{l}\text { Frontiers of Chemical } \\
\text { Engineering in China }\end{array}$ & $\begin{array}{l}\text { Preference Evaluation } \\
\text { OR Econometrics }\end{array}$ & $\begin{array}{l}\text { Evaluation of the post-combustion } \\
\text { sector and its involvement in energy } \\
\text { production }\end{array}$ \\
\hline Guasco et al. [55] & 2011 & $\begin{array}{c}\text { Journal of Physical } \\
\text { Chemistry A }\end{array}$ & Monte Carlo Methods & $\begin{array}{l}\text { Study of the origin of anharmonic } \\
\text { effects through Monte Carlo analysis }\end{array}$ \\
\hline Arthur et al. [56] & 2012 & Energy Economics & $\begin{array}{l}\text { Preference Evaluation } \\
\text { OR Econometrics }\end{array}$ & $\begin{array}{l}\text { Calculation of the elasticity of } \\
\text { domestic energy demand at price } \\
\text { and income in Mozambique }\end{array}$ \\
\hline Heun and de Wit [57] & 2012 & Energy Policy & $\begin{array}{l}\text { Regression Analysis } \\
\text { OR Parametric Model }\end{array}$ & $\begin{array}{l}\text { Analysis of the rise in the price of oil } \\
\text { in relation to the energy transition }\end{array}$ \\
\hline
\end{tabular}


Table A1. Cont.

\begin{tabular}{|c|c|c|c|c|}
\hline Authors & Years & Source Title & Evaluation Method & Objective and Application Context \\
\hline Schaede et al. [58] & 2013 & Design and Assessment & $\begin{array}{l}\text { Life Cycle Assessment, } \\
\text { Life Cycle Cost }\end{array}$ & $\begin{array}{l}\text { Evaluation and design of electric } \\
\text { energy storage }\end{array}$ \\
\hline Eising et al. [59] & 2014 & Applied Energy & $\begin{array}{l}\text { Geographical } \\
\text { Information System }\end{array}$ & $\begin{array}{l}\text { Analysis of transport and supply } \\
\text { chain integration }\end{array}$ \\
\hline $\begin{array}{c}\text { Evanno and } \\
\text { Weinberger [60] }\end{array}$ & 2014 & $\begin{array}{l}\text { Techniques-Sciences- } \\
\text { Methodes }\end{array}$ & $\begin{array}{l}\text { Environmental Impact } \\
\text { Assessment }\end{array}$ & $\begin{array}{l}\text { Analysis of specific feedback } \\
\text { processes related to the biogas of } \\
\text { accidents }\end{array}$ \\
\hline King [61] & 2014 & Energy & Life Cycle Assessment & $\begin{array}{l}\text { Comparison between the energy } \\
\text { performance of systems in the } \\
\text { energy transition }\end{array}$ \\
\hline Nordman [62] & 2014 & Renewable Energy & Life Cycle Cost & $\begin{array}{c}\text { Analysis of wind farms to power tea } \\
\text { factories in Kenya }\end{array}$ \\
\hline $\begin{array}{l}\text { Zimmermann et al. } \\
\text { [63] }\end{array}$ & 2014 & $\begin{array}{l}\text { Metallurgical Research } \\
\text { and Technology }\end{array}$ & Life Cycle Assessment & $\begin{array}{l}\text { Importance of electric vehicles in the } \\
\text { energy transition }\end{array}$ \\
\hline Bachmann [64] & 2015 & $\begin{array}{l}\text { Environmental Science } \\
\text { and Technology }\end{array}$ & Cost-Benefit Analysis & $\begin{array}{l}\text { Strengths and disadvantages of an } \\
\text { approach to the environmental } \\
\text { economy }\end{array}$ \\
\hline Wesseh et al. [65] & 2015 & $\begin{array}{l}\text { Journal of Cleaner } \\
\text { Production }\end{array}$ & Cost-Benefit Analysis & $\begin{array}{l}\text { Benefit analysis for renewable } \\
\text { energy research and development } \\
\text { programs in Liberia }\end{array}$ \\
\hline $\begin{array}{l}\text { Zimmermann et al. } \\
{[66]}\end{array}$ & 2015 & $\begin{array}{l}\text { Integrated } \\
\text { Environmental } \\
\text { Assessment and } \\
\text { Management }\end{array}$ & Life Cycle Assessment & $\begin{array}{l}\text { Study on the importance of electric } \\
\text { vehicles for the energy transition }\end{array}$ \\
\hline Calvert [67] & 2016 & $\begin{array}{l}\text { Progress in Human } \\
\text { Geography }\end{array}$ & $\begin{array}{c}\text { Geographical } \\
\text { Information System }\end{array}$ & $\begin{array}{c}\text { Analysis of geographical } \\
\text { contributions, study of energy and } \\
\text { energy futures. }\end{array}$ \\
\hline Cucchiella et al. [41] & 2016 & $\begin{array}{l}\text { Energy Conversion and } \\
\text { Management }\end{array}$ & $\begin{array}{l}\text { Cost-Benefit Analysis, } \\
\text { Sensitivity Analisis }\end{array}$ & $\begin{array}{c}\text { Evaluation of small-scale } \\
\text { photovoltaic systems and results }\end{array}$ \\
\hline Herbert et al. [68] & 2016 & $\begin{array}{l}\text { Sustainable Production } \\
\text { and Consumption }\end{array}$ & Life Cycle Assessment & $\begin{array}{c}\text { A proposal for types of greenhouse } \\
\text { gas emissions }\end{array}$ \\
\hline Lizana et al. [69] & 2016 & Energy and Buildings & $\begin{array}{l}\text { Multiple Criteria } \\
\text { Decision Analysis }\end{array}$ & $\begin{array}{c}\text { Economic, environmental, and social } \\
\text { assessment for a residential energy } \\
\text { retrofit }\end{array}$ \\
\hline Sager-Klauß [70] & 2016 & $\begin{array}{c}\mathrm{A}+\mathrm{BE} \text { Architecture and } \\
\text { the Built Environment }\end{array}$ & $\begin{array}{l}\text { Geographical } \\
\text { Information System }\end{array}$ & $\begin{array}{l}\text { Support for sustainable energy } \\
\text { transition planning in small and } \\
\text { medium-sized communities }\end{array}$ \\
\hline Sgouridis et al. [71] & 2016 & $\begin{array}{c}\text { Renewable and } \\
\text { Sustainable Energy } \\
\text { Reviews }\end{array}$ & Cost-Benefit Analysis & $\begin{array}{c}\text { Analysis of renewable energy costs } \\
\text { in the United Arab Emirates }\end{array}$ \\
\hline $\begin{array}{c}\text { Carlier and } \\
\text { Chardonnet [72] }\end{array}$ & 2017 & $\begin{array}{l}\text { Environnement, } \\
\text { Risques et Sante }\end{array}$ & $\begin{array}{l}\text { Environmental Impact } \\
\text { Assessment }\end{array}$ & $\begin{array}{l}\text { Search for the path with the lowest } \\
\text { environmental and health impact for } \\
\text { the reconstruction of an power line }\end{array}$ \\
\hline Kaltenegger et al. [73] & 2017 & Energy Policy & Cost-Benefit Analysis & $\begin{array}{c}\text { Input-output and trend-based } \\
\text { energy cost study in Germany and } \\
\text { EU }\end{array}$ \\
\hline
\end{tabular}


Table A1. Cont.

\begin{tabular}{|c|c|c|c|c|}
\hline Authors & Years & Source Title & Evaluation Method & Objective and Application Context \\
\hline Ketzer et al. [74] & 2017 & Biomass and Bioenergy & $\begin{array}{l}\text { Geographical } \\
\text { Information System }\end{array}$ & $\begin{array}{l}\text { Assessment of the sustainable } \\
\text { potential of pasture biomass for } \\
\text { energy supply }\end{array}$ \\
\hline Kraan et al. [75] & 2017 & $\begin{array}{l}\text { Advances in Intelligent } \\
\text { Systems and } \\
\text { Computing }\end{array}$ & Cost-Benefit Analysis & $\begin{array}{l}\text { Models and studies for adaptation } \\
\text { to climate change }\end{array}$ \\
\hline $\begin{array}{c}\text { Li and Trutnevyte } \\
\text { [76] }\end{array}$ & 2017 & Applied Energy & $\begin{array}{l}\text { Quantitative Analysis, } \\
\text { Monte Carlo Methods }\end{array}$ & $\begin{array}{l}\text { Analysis to reduce UK greenhouse } \\
\text { gas emissions by } 2050\end{array}$ \\
\hline Loßner et al. [77] & 2017 & Energy Economics & Cost-Benefit Analysis & $\begin{array}{l}\text { Simulation of alternative scenarios } \\
\text { on renewable energy }\end{array}$ \\
\hline Muratori et al. [78] & 2017 & $\begin{array}{l}\text { Renewable and } \\
\text { Sustainable Energy } \\
\text { Reviews }\end{array}$ & $\begin{array}{l}\text { Cost-Benefit Analysis, } \\
\text { Sensitivity Analysis }\end{array}$ & $\begin{array}{l}\text { Assessment of the increase in the } \\
\text { cost of building large energy plants } \\
\text { in the US }\end{array}$ \\
\hline $\begin{array}{l}\text { Rakotoson and } \\
\text { Praene [79] }\end{array}$ & 2017 & $\begin{array}{l}\text { Journal of Cleaner } \\
\text { Production }\end{array}$ & Life Cycle Assessment & $\begin{array}{l}\text { Assessment of the environmental } \\
\text { impacts of energy production in the } \\
\text { French overseas territories }\end{array}$ \\
\hline Scipioni et al. [80] & 2017 & $\begin{array}{l}\text { Hydrogen Economy: } \\
\text { Supply Chain, Life } \\
\text { Cycle Analysis and } \\
\text { Energy Transition for } \\
\text { Sustainability }\end{array}$ & $\begin{array}{l}\text { Multiple Criteria } \\
\text { Decision Analysis }\end{array}$ & $\begin{array}{l}\text { Analysis of the difficulties for a } \\
\text { sustainable hydrogen economy }\end{array}$ \\
\hline Serp et al. [81] & 2017 & Energies & Life Cycle Assessment & $\begin{array}{l}\text { Evaluation of nuclear energy } \\
\text { recycling }\end{array}$ \\
\hline $\begin{array}{l}\text { Wan Ahmad et al. } \\
\text { [82] }\end{array}$ & 2017 & $\begin{array}{l}\text { Journal of Cleaner } \\
\text { Production }\end{array}$ & $\begin{array}{l}\text { Multiple Criteria } \\
\text { Decision Analysis }\end{array}$ & $\begin{array}{l}\text { Quantitative assessment of the } \\
\text { forces necessary for the sustainable } \\
\text { management of the supply chain }\end{array}$ \\
\hline Wang et al. [83] & 2017 & Energy Procedia & $\begin{array}{l}\text { Life Cycle Cost, } \\
\text { Multiple Criteria } \\
\text { Decision Analysis }\end{array}$ & $\begin{array}{l}\text { Resilience analysis for energy } \\
\text { systems }\end{array}$ \\
\hline Danielson et al. [84] & 2018 & $\begin{array}{l}\text { Lecture Notes in } \\
\text { Business Information } \\
\text { Processing }\end{array}$ & $\begin{array}{l}\text { Multiple Criteria } \\
\text { Decision Analysis }\end{array}$ & $\begin{array}{l}\text { Multi-policy analysis of sustainable } \\
\text { choices in Jordan }\end{array}$ \\
\hline Deakin and Reid [85] & 2018 & $\begin{array}{l}\text { Journal of Cleaner } \\
\text { Production }\end{array}$ & Cost-Benefit Analysis & $\begin{array}{l}\text { Smart city analytics and behavior } \\
\text { tips }\end{array}$ \\
\hline Desthieux et al. [86] & 2018 & $\begin{array}{l}\text { Frontiers in Built } \\
\text { Environment }\end{array}$ & $\begin{array}{l}\text { Geographical } \\
\text { Information System }\end{array}$ & $\begin{array}{l}\text { Presentation of a methodology for } \\
\text { assessing solar radiation and energy } \\
\text { production on building roofs and } \\
\text { vertical facades in the city center }\end{array}$ \\
\hline Ghannadzadeh [47] & 2018 & $\begin{array}{l}\text { Chemical Engineering } \\
\text { Research and Design }\end{array}$ & $\begin{array}{l}\text { Life Cycle Assessment, } \\
\text { Monte Carlo Methods }\end{array}$ & $\begin{array}{l}\text { Assessment of the environmental } \\
\text { impacts of the chemical components } \\
\text { of vinyl chloride }\end{array}$ \\
\hline Ghannadzadeh [48] & 2018 & Renewable Energy & $\begin{array}{l}\text { Life Cycle Assessment, } \\
\text { Environmental Impact } \\
\text { Assessment, Monte } \\
\text { Carlo Methods }\end{array}$ & $\begin{array}{l}\text { Assessment of production process } \\
\text { for rigid polyurethane synthesis }\end{array}$ \\
\hline Huang et al. [87] & 2018 & $\begin{array}{l}\text { Dianli Xitong Zi- } \\
\text { donghua/Automation } \\
\text { of Electric Power } \\
\text { Systems }\end{array}$ & Quantitative Analysis & $\begin{array}{c}\text { Analysis and control of carbon } \\
\text { market risk }\end{array}$ \\
\hline
\end{tabular}


Table A1. Cont.

\begin{tabular}{|c|c|c|c|c|}
\hline Authors & Years & Source Title & Evaluation Method & Objective and Application Context \\
\hline Li and Pye [88] & 2018 & $\begin{array}{l}\text { Energy Research and } \\
\text { Social Science }\end{array}$ & Quantitative Analysis & $\begin{array}{c}\text { Experts assess uncertainties in UK } \\
\text { energy transition }\end{array}$ \\
\hline $\begin{array}{l}\text { López Prol and } \\
\text { Steininger [89] }\end{array}$ & 2018 & $\begin{array}{c}\text { Progress in } \\
\text { Photovoltaics: Research } \\
\text { and Applications }\end{array}$ & Cost-Benefit Analysis & $\begin{array}{c}\text { Calculation of the social profitability } \\
\text { of the photovoltaic system in } \\
\text { Germany }\end{array}$ \\
\hline $\begin{array}{l}\text { Maennel and Kim } \\
\text { [90] }\end{array}$ & 2018 & Energies & Monte Carlo Methods & $\begin{array}{l}\text { Assessment of the reduction of air } \\
\text { pollutants produced by South Korea } \\
\text { and Germany until } 2030\end{array}$ \\
\hline Meschede et al. [91] & 2018 & $\begin{array}{l}\text { Energy Conversion and } \\
\text { Management }\end{array}$ & Cost-Benefit Analysis & $\begin{array}{l}\text { Analysis of a } 100 \% \text { renewable } \\
\text { subtropical island from the point of } \\
\text { view of distribution }\end{array}$ \\
\hline Meylan et al. [92] & 2018 & Waste Management & Life Cycle Assessment & $\begin{array}{l}\text { Assessment of waste management } \\
\text { systems }\end{array}$ \\
\hline Mullally et al. [93] & 2018 & $\begin{array}{l}\text { Environmental Science } \\
\text { and Policy }\end{array}$ & $\begin{array}{l}\text { Environmental Impact } \\
\text { Assessment }\end{array}$ & $\begin{array}{l}\text { Analysis of participation for the } \\
\text { integration of environmental policy }\end{array}$ \\
\hline Raoux et al. [25] & 2018 & Marine Policy & $\begin{array}{l}\text { Environmental Impact } \\
\text { Assessment }\end{array}$ & $\begin{array}{l}\text { Analysis of alternative scenarios of } \\
\text { how the ecosystem will be able to } \\
\text { act in wind farms in Normandy }\end{array}$ \\
\hline $\begin{array}{l}\text { Shmelev and } \\
\text { Shmeleva [94] }\end{array}$ & 2018 & $\begin{array}{l}\text { Sustainable } \\
\text { Development }\end{array}$ & $\begin{array}{l}\text { Multiple Criteria } \\
\text { Decision Analysis }\end{array}$ & $\begin{array}{l}\text { Assessment of urban sustainability } \\
\text { performance through indicators of } \\
57 \text { cities around the world }\end{array}$ \\
\hline $\begin{array}{l}\text { Skoczkowski et al. } \\
\text { [95] }\end{array}$ & 2018 & $\begin{array}{l}\text { Mitigation and } \\
\text { Adaptation Strategies } \\
\text { for Global Change }\end{array}$ & $\begin{array}{l}\text { Environmental Impact } \\
\text { Assessment }\end{array}$ & $\begin{array}{l}\text { Estimation of the costs and benefits } \\
\text { of power plants in Poland in the } \\
\text { transition to a low-carbon economy }\end{array}$ \\
\hline $\begin{array}{l}\text { Torabi Moghadam } \\
\text { et al. [96] }\end{array}$ & 2018 & $\begin{array}{l}\text { Sustainable Cities and } \\
\text { Society }\end{array}$ & $\begin{array}{l}\text { Geographical } \\
\text { Information System }\end{array}$ & $\begin{array}{c}\text { Estimate of energy consumption of a } \\
\text { large number of residential building } \\
\text { stocks for space heating }\end{array}$ \\
\hline Tronchin et al. [97] & 2018 & Energy & $\begin{array}{l}\text { Regression Analysis } \\
\text { OR Parametric Model }\end{array}$ & $\begin{array}{l}\text { Test of an approach to link } \\
\text { operational performance analytics } \\
\text { with passive home design }\end{array}$ \\
\hline Walker et al. [98] & 2018 & Applied Energy & $\begin{array}{l}\text { Monte Carlo Methods, } \\
\text { Sensitivity Analysis }\end{array}$ & $\begin{array}{l}\text { Comparative analysis of solutions } \\
\text { for aggregated residential } \\
\text { prosumers in electricity markets }\end{array}$ \\
\hline Wen et al. [99] & 2018 & Energy Procedia & Quantitative Analysis & $\begin{array}{l}\text { Assessment of China's energy sector } \\
\text { transition strategy based on a } \\
\text { dynamic simulation model }\end{array}$ \\
\hline Zaman et al. [100] & 2018 & Energy Policy & $\begin{array}{l}\text { Multiple Criteria } \\
\text { Decision Analysis }\end{array}$ & $\begin{array}{l}\text { Literature review of Bangladesh's } \\
\text { choices towards a sustainable policy }\end{array}$ \\
\hline Zeyringer et al. [101] & 2018 & Renewable Energy & $\begin{array}{l}\text { Quantitative Analysis, } \\
\text { Sensitivity Analysis }\end{array}$ & $\begin{array}{l}\text { Analysis of the potential } \\
\text { contribution of marine energy in the } \\
\text { UK from the point of view of energy } \\
\text { systems }\end{array}$ \\
\hline $\begin{array}{l}\text { Zimmermann and } \\
\text { Pye [102] }\end{array}$ & 2018 & Energy Policy & $\begin{array}{l}\text { Environmental Impact } \\
\text { Assessment }\end{array}$ & $\begin{array}{c}\text { Assessing the impacts of } \\
\text { decarbonization and what effects } \\
\text { they have on UK energy and climate } \\
\text { policies }\end{array}$ \\
\hline Bódis et al. [103] & 2019 & $\begin{array}{c}\text { Renewable and } \\
\text { Sustainable Energy } \\
\text { Reviews }\end{array}$ & Cost-Benefit Analysis & $\begin{array}{l}\text { Geospatial methods to quantify the } \\
\text { roof area to place photovoltaic } \\
\text { systems }\end{array}$ \\
\hline
\end{tabular}


Table A1. Cont.

\begin{tabular}{|c|c|c|c|c|}
\hline Authors & Years & Source Title & Evaluation Method & Objective and Application Context \\
\hline $\begin{array}{l}\text { Böing and Regett } \\
\text { [104] }\end{array}$ & 2019 & Energies & Cost-Benefit Analysis & $\begin{array}{l}\text { Analysis of } \mathrm{CO}_{2} \text { emissions via } \\
\text { multi-energy carriers }\end{array}$ \\
\hline Burnley [105] & 2019 & Detritus & Life Cycle Assessment & Production of energy from waste \\
\hline Camargo et al. [106] & 2019 & GeoScape & $\begin{array}{l}\text { Geographical } \\
\text { Information System }\end{array}$ & $\begin{array}{c}\text { Estimation of the topology of } \\
\text { Bavaria's medium- and low-voltage } \\
\text { networks }\end{array}$ \\
\hline Cavalcanti et al. [107] & 2019 & Energy & Sensitivity Analysis & $\begin{array}{l}\text { Analysis to quantify the } \\
\text { environmental impacts associated } \\
\text { with eucalyptus combustion }\end{array}$ \\
\hline Coroiu [108] & 2019 & $\begin{array}{l}\text { Proceedings of } 2019 \text { 8th } \\
\text { International } \\
\text { Conference on Modern } \\
\text { Power Systems, MPS } \\
2019\end{array}$ & $\begin{array}{l}\text { Multiple Criteria } \\
\text { Decision Analysis }\end{array}$ & $\begin{array}{l}\text { Evaluation of the performance of } \\
\text { energy efficiency solutions of service } \\
\text { consumers }\end{array}$ \\
\hline $\begin{array}{l}\text { Correa-Florez et al. } \\
\text { [109] }\end{array}$ & 2019 & Energies & $\begin{array}{l}\text { Cost-Benefit Analysis, } \\
\text { Monte Carlo Methods }\end{array}$ & $\begin{array}{l}\text { Comparative analysis of solutions } \\
\text { for aggregated residential } \\
\text { prosumers in electricity markets }\end{array}$ \\
\hline Costantini et al. [110] & 2019 & $\begin{array}{l}\text { Eurasian Business } \\
\text { Review }\end{array}$ & $\begin{array}{l}\text { Preference Evaluation } \\
\text { OR Econometrics }\end{array}$ & $\begin{array}{l}\text { Evaluation of different sectors and } \\
\text { their behavior in the introduction of } \\
\text { new low-consumption technologies }\end{array}$ \\
\hline Drouilles et al. [111] & 2019 & Energy Efficiency & $\begin{array}{l}\text { Environmental Impact } \\
\text { Assessment }\end{array}$ & $\begin{array}{c}\text { Debate on the energy transition } \\
\text { through residential areas in } \\
\text { Switzerland }\end{array}$ \\
\hline $\begin{array}{l}\text { Ghannadzadeh and } \\
\text { Meymivand [112] }\end{array}$ & 2019 & $\begin{array}{l}\text { Clean Technologies and } \\
\text { Environmental Policy }\end{array}$ & $\begin{array}{l}\text { Life Cycle Assessment, } \\
\text { Monte Carlo Methods }\end{array}$ & $\begin{array}{l}\text { Evaluation of the ethylene oxide } \\
\text { production process and solutions }\end{array}$ \\
\hline $\begin{array}{l}\text { Ghannadzadeh and } \\
\text { Tarighaleslami [113] }\end{array}$ & 2019 & $\begin{array}{c}\text { Environmental } \\
\text { Progress and } \\
\text { Sustainable Energy }\end{array}$ & $\begin{array}{l}\text { Monte Carlo Methods, } \\
\text { Life Cycle Assessment }\end{array}$ & $\begin{array}{l}\text { Assessment of harmful materials in } \\
\text { chlorine production }\end{array}$ \\
\hline $\begin{array}{l}\text { Jenniches and Worrell } \\
\text { [114] }\end{array}$ & 2019 & $\begin{array}{l}\text { Energy for Sustainable } \\
\text { Development }\end{array}$ & $\begin{array}{l}\text { Environmental Impact } \\
\text { Assessment }\end{array}$ & $\begin{array}{c}\text { Analysis of the benefits of } \\
\text { photovoltaic systems in a German } \\
\text { region }\end{array}$ \\
\hline Jin et al. [115] & 2019 & $\begin{array}{l}\text { Renewable and } \\
\text { Sustainable Energy } \\
\text { Reviews }\end{array}$ & Life Cycle Assessment & $\begin{array}{l}\text { Estimation of water consumption of } \\
\text { renewable energy }\end{array}$ \\
\hline Leporini et al. [116] & 2019 & Renewable Energy & Life Cycle Assessment & $\begin{array}{l}\text { A model for the reuse of oil and gas } \\
\text { platforms }\end{array}$ \\
\hline Marcucci et al. [117] & 2019 & Applied Energy & Monte Carlo Methods & $\begin{array}{l}\text { Assessment of energy transition and } \\
\text { climate change at the end of the } \\
\text { century }\end{array}$ \\
\hline $\begin{array}{l}\text { Markov and } \\
\text { Rajaković [118] }\end{array}$ & 2019 & $\begin{array}{l}\text { Energy Conversion and } \\
\text { Management }\end{array}$ & Sensitivity Analysis & $\begin{array}{l}\text { Feasibility study in the direction of } \\
\text { including significant impacts of the } \\
\text { line rating and market conditions }\end{array}$ \\
\hline Mohajeri et al. [119] & 2019 & Renewable Energy & Quantitative Analysis & $\begin{array}{c}\text { Assessment of sustainable } \\
\text { development scenarios for a Swiss } \\
\text { village until } 2050\end{array}$ \\
\hline Nitsch et al. [120] & 2019 & $\begin{array}{l}\text { Energy, Sustainability } \\
\text { and Society }\end{array}$ & Sensitivity Analysis & $\begin{array}{c}\text { Estimation of land availability for } \\
\text { wind energy }\end{array}$ \\
\hline
\end{tabular}


Table A1. Cont.

\begin{tabular}{|c|c|c|c|c|}
\hline Authors & Years & Source Title & Evaluation Method & Objective and Application Context \\
\hline $\begin{array}{l}\text { Pedinotti-Castelle } \\
\quad \text { et al. [121] }\end{array}$ & 2019 & $\begin{array}{l}\text { Renewable and } \\
\text { Sustainable Energy } \\
\text { Reviews }\end{array}$ & Life Cycle Cost & $\begin{array}{l}\text { Cost efficiency assessment and } \\
\text { sustainable technology solutions in } \\
\text { the residential sector }\end{array}$ \\
\hline $\begin{array}{l}\text { Selvakkumaran and } \\
\text { Ahlgren [122] }\end{array}$ & 2019 & Technology in Society & Quantitative Analysis & $\begin{array}{l}\text { Study of the energy transition on } \\
\text { household behavior }\end{array}$ \\
\hline $\begin{array}{l}\text { Stremke and Schöbel } \\
\text { [123] }\end{array}$ & 2019 & $\begin{array}{l}\text { Smart and Sustainable } \\
\text { Built Environment }\end{array}$ & $\begin{array}{l}\text { Environmental Impact } \\
\text { Assessment, Multiple } \\
\text { Criteria Decision } \\
\text { Analysis }\end{array}$ & $\begin{array}{l}\text { Presentation of a design method } \\
\text { aimed at the energy transition }\end{array}$ \\
\hline $\begin{array}{l}\text { Thonemann and } \\
\text { Maga [124] }\end{array}$ & 2019 & $\begin{array}{l}\text { Sustainable Production, } \\
\text { Life Cycle Engineering } \\
\text { and Management }\end{array}$ & Life Cycle Assessment & $\begin{array}{c}\text { Environmental analysis of different } \\
\text { German energy scenarios }\end{array}$ \\
\hline Watari et al. [125] & 2019 & $\begin{array}{l}\text { Resources, } \\
\text { Conservation and } \\
\text { Recycling }\end{array}$ & Life Cycle Assessment & $\begin{array}{l}\text { Saving mineral resources through } \\
\text { the energy transition }\end{array}$ \\
\hline Yang et al. [126] & 2019 & $\begin{array}{c}\text { Nature } \\
\text { Communications }\end{array}$ & Quantitative Analysis & $\begin{array}{l}\text { Breakdown of energy transfer gap } \\
\text { laws revealed by full-dimensional } \\
\text { quantum scattering between } \\
\text { hydrogen fluoride (HF) molecules }\end{array}$ \\
\hline Yang et al. [127] & 2019 & Energy Procedia & Quantitative Analysis & $\begin{array}{c}\text { Study of the average coal } \\
\text { consumption rate in China and } \\
\text { investments towards the energy } \\
\text { transition }\end{array}$ \\
\hline Yu et al. [128] & 2019 & Energy & $\begin{array}{l}\text { Monte Carlo Methods, } \\
\text { Sensitivity Analysis }\end{array}$ & $\begin{array}{c}\text { Analysis of the reliability of the } \\
\text { electrical system in Taiwan }\end{array}$ \\
\hline Albers et al. [129] & 2020 & $\begin{array}{l}\text { International Journal of } \\
\text { Life Cycle Assessment }\end{array}$ & Life Cycle Assessment & $\begin{array}{l}\text { Evaluation of the use of forest wood } \\
\text { residues }\end{array}$ \\
\hline Albers et al. [130] & 2020 & $\begin{array}{l}\text { Science of the Total } \\
\text { Environment }\end{array}$ & Sensitivity Analysis & $\begin{array}{l}\text { Analysis of the impacts of organic } \\
\text { carbon in the soil }\end{array}$ \\
\hline Ameur et al. [39] & 2020 & $\begin{array}{l}\text { Journal of Cleaner } \\
\text { Production }\end{array}$ & Cost-Benefit Analysis & $\begin{array}{l}\text { Evaluation of photovoltaic system } \\
\text { performance }\end{array}$ \\
\hline Atkins [131] & 2020 & Political Geography & $\begin{array}{l}\text { Environmental Impact } \\
\text { Assessment }\end{array}$ & $\begin{array}{l}\text { Evaluation of the use and benefits of } \\
\text { hydroelectric power against } \\
\text { anti-dam movements }\end{array}$ \\
\hline Banacloche et al. [44] & 2020 & $\begin{array}{l}\text { Science of the Total } \\
\text { Environment }\end{array}$ & Life Cycle Assessment & $\begin{array}{l}\text { Sustainability assessment of a } \\
\text { hybrid concentrated solar power } \\
\text { and biomass plant }\end{array}$ \\
\hline $\begin{array}{l}\text { Braunholtz-Speight } \\
\text { et al. [132] }\end{array}$ & 2020 & Nature Energy & Quantitative Analysis & $\begin{array}{l}\text { Quantitative analysis of UK } \\
\text { community energy project business } \\
\text { models, funding mechanisms, and } \\
\text { financial results }\end{array}$ \\
\hline Brunet et al. [24] & 2020 & $\begin{array}{l}\text { Sustainability } \\
\text { (Switzerland) }\end{array}$ & $\begin{array}{l}\text { Multiple Criteria } \\
\text { Decision Analysis }\end{array}$ & $\begin{array}{c}\text { Evaluation of a photovoltaic system } \\
\text { in Madagascar }\end{array}$ \\
\hline Cox et al. [46] & 2020 & Applied Energy & $\begin{array}{l}\text { Life Cycle Assessment, } \\
\text { Cost-Benefit Analysis, } \\
\text { Sensitivity Analysis }\end{array}$ & $\begin{array}{c}\text { Life cycle analysis and total costs of } \\
\text { ownership of current and future } \\
\text { vehicles }\end{array}$ \\
\hline Dean et al. [133] & 2020 & $\begin{array}{l}\text { International Journal of } \\
\text { Greenhouse Gas } \\
\text { Control }\end{array}$ & Cost-Benefit Analysis & Analysis of marine $\mathrm{CO}_{2}$ monitoring \\
\hline
\end{tabular}


Table A1. Cont.

\begin{tabular}{|c|c|c|c|c|}
\hline Authors & Years & Source Title & Evaluation Method & Objective and Application Context \\
\hline $\begin{array}{l}\text { Ghannadzadeh and } \\
\text { Tarighaleslami [42] }\end{array}$ & 2020 & $\begin{array}{l}\text { Sustainable Energy } \\
\text { Technologies and } \\
\text { Assessments }\end{array}$ & Life Cycle Assessment & $\begin{array}{l}\text { Assessment of sustainability in the } \\
\text { production processes of glycerine }\end{array}$ \\
\hline Harajli et al. [49] & 2020 & Energy Policy & Cost-Benefit Analysis & $\begin{array}{l}\text { Integrated evaluation of hybrid } \\
\text { solar-diesel systems for } \\
\text { performance assessment }\end{array}$ \\
\hline $\begin{array}{l}\text { Höfer and Madlener } \\
{[134]}\end{array}$ & 2020 & Energy Policy & $\begin{array}{l}\text { Multiple Criteria } \\
\text { Decision Analysis }\end{array}$ & $\begin{array}{l}\text { Evaluation of the choices of different } \\
\text { stakeholders on different energy } \\
\text { transition scenarios }\end{array}$ \\
\hline Hu et al. [135] & 2020 & $\begin{array}{c}\text { Dianli Xitong Zi- } \\
\text { donghua/Automation } \\
\text { of Electric Power } \\
\text { Systems }\end{array}$ & $\begin{array}{l}\text { Cost-Benefit Analysis, } \\
\text { Sensitivity Analysis }\end{array}$ & $\begin{array}{l}\text { Assessment of the effects of carbon } \\
\text { on society and possible solutions }\end{array}$ \\
\hline Jiang et al. [45] & 2020 & Renewable Energy & Life Cycle Assessment & $\begin{array}{l}\text { Assessment of the benefits of pellet } \\
\text { production in China }\end{array}$ \\
\hline Kim et al. [136] & 2020 & Applied Energy & $\begin{array}{l}\text { Regression Analysis } \\
\text { OR Parametric Model }\end{array}$ & $\begin{array}{l}\text { Analysis of public opinion change } \\
\text { on the energy transition }\end{array}$ \\
\hline Kokkinos et al. [137] & 2020 & $\begin{array}{l}\text { Science of the Total } \\
\text { Environment }\end{array}$ & Quantitative Analysis & $\begin{array}{l}\text { Energy transition supported by } \\
\text { Fuzzy cognitive map modeling }\end{array}$ \\
\hline $\begin{array}{l}\text { Middelhauve et al. } \\
\text { [138] }\end{array}$ & 2020 & $\begin{array}{c}\text { ECOS } \\
\text { 2020-Proceedings of } \\
\text { the 33rd International } \\
\text { Conference on } \\
\text { Efficiency, Cost, } \\
\text { Optimization, } \\
\text { Simulation and } \\
\text { Environmental Impact } \\
\text { of Energy Systems }\end{array}$ & $\begin{array}{l}\text { Multiple Criteria } \\
\text { Decision Analysis }\end{array}$ & $\begin{array}{l}\text { Evaluation of key performance } \\
\text { indicators on building energy } \\
\text { system planning }\end{array}$ \\
\hline
\end{tabular}

\begin{tabular}{|c|c|c|c|c|}
\hline Miranda et al. [139] & 2020 & Energies & Sensitivity Analysis & $\begin{array}{l}\text { Evaluation of the development of } \\
\text { geothermal energy in regions of } \\
\text { North America }\end{array}$ \\
\hline Muñoz et al. [140] & 2020 & $\begin{array}{c}\text { Energy Strategy } \\
\text { Reviews }\end{array}$ & $\begin{array}{c}\text { Geographical } \\
\text { Information System }\end{array}$ & $\begin{array}{l}\text { Assessment of the energy } \\
\text { performance of cities and future } \\
\text { scenarios }\end{array}$ \\
\hline Nechifor et al. [141] & 2020 & World Development & $\begin{array}{l}\text { Environmental Impact } \\
\text { Assessment }\end{array}$ & $\begin{array}{l}\text { Assessment of steel reuse to support } \\
\text { a circular economy in China }\end{array}$ \\
\hline Paltsev [142] & 2020 & $\begin{array}{l}\text { Economics of Energy } \\
\text { and Environmental } \\
\text { Policy }\end{array}$ & Quantitative Analysis & $\begin{array}{l}\text { Quantitative analysis of the } \\
\text { decision-making risks associated } \\
\text { with different energy paths }\end{array}$ \\
\hline Partidário et al. [143] & 2020 & $\begin{array}{l}\text { International Journal of } \\
\text { Hydrogen Energy }\end{array}$ & $\begin{array}{l}\text { Life Cycle Assessment, } \\
\text { Sensitivity Analysis }\end{array}$ & $\begin{array}{l}\text { Analysis and cost assessments of the } \\
\text { hydrogen economy approach }\end{array}$ \\
\hline $\begin{array}{l}\text { Patouillard et al. } \\
\text { [144] }\end{array}$ & 2020 & $\begin{array}{l}\text { International Journal of } \\
\text { Life Cycle Assessment }\end{array}$ & $\begin{array}{l}\text { Life Cycle Assessment, } \\
\text { Sensitivity Analysis, } \\
\text { Quantitative Analysis }\end{array}$ & $\begin{array}{c}\text { Difference between Consequential } \\
\text { Life Cycle Assessment (C-LCA) and } \\
\text { LCA }\end{array}$ \\
\hline Raugei et al. [145] & 2020 & Energies & Life Cycle Assessment & $\begin{array}{l}\text { Assessment of greenhouse gas } \\
\text { emissions and reduction of } \\
\text { non-renewable energy through the } \\
\text { use of home storage batteries in } \\
\text { California }\end{array}$ \\
\hline
\end{tabular}


Table A1. Cont.

\begin{tabular}{|c|c|c|c|c|}
\hline Authors & Years & Source Title & Evaluation Method & Objective and Application Context \\
\hline Rohe [146] & 2020 & $\begin{array}{c}\text { Environmental } \\
\text { Innovation and Societal } \\
\text { Transitions }\end{array}$ & $\begin{array}{l}\text { Geographical } \\
\text { Information System }\end{array}$ & $\begin{array}{l}\text { Analysis of wind energy rooted in } \\
\text { the national and global territory }\end{array}$ \\
\hline $\begin{array}{l}\text { Sareen and Grandin } \\
\text { [147] }\end{array}$ & 2020 & $\begin{array}{l}\text { Geografiska Annaler, } \\
\text { Series B: Human } \\
\text { Geography }\end{array}$ & $\begin{array}{l}\text { Preference evaluation } \\
\text { OR econometrics }\end{array}$ & $\begin{array}{c}\text { Oslo } 2019 \text { and Lisbon } 2020 \text { European } \\
\text { Green Capital (EGC) Winners } \\
\text { Ratings }\end{array}$ \\
\hline Saretta et al. [148] & 2020 & $\begin{array}{c}\text { Sustainable Cities and } \\
\text { Society }\end{array}$ & $\begin{array}{l}\text { Geographical } \\
\text { Information System }\end{array}$ & $\begin{array}{c}\text { GIS integration for urban retrofit } \\
\text { estimation }\end{array}$ \\
\hline Seck et al. [149] & 2020 & $\begin{array}{l}\text { Resources, } \\
\text { Conservation and } \\
\text { Recycling }\end{array}$ & Life Cycle Assessment & $\begin{array}{l}\text { Assessment of the impact of copper } \\
\text { availability on the energy transition }\end{array}$ \\
\hline Sharma et al. [150] & 2020 & $\begin{array}{c}\text { Environmental } \\
\text { Innovation and Societal } \\
\text { Transitions }\end{array}$ & $\begin{array}{l}\text { Multiple Criteria } \\
\text { Decision Analysis, } \\
\text { Sensitivity Analysis }\end{array}$ & $\begin{array}{l}\text { Analysis of decarbonization } \\
\text { scenarios in Ireland }\end{array}$ \\
\hline $\begin{array}{l}\text { Shaw-Williams and } \\
\text { Susilawati [151] }\end{array}$ & 2020 & Applied Energy & Monte Carlo Methods & $\begin{array}{c}\text { Virtual network measurement } \\
\text { assessment to address social equity } \\
\text { in the energy transition for } \\
\text { Australia's community housing } \\
\text { sector }\end{array}$ \\
\hline $\begin{array}{l}\text { Taherahmadi et al. } \\
\text { [152] }\end{array}$ & 2020 & $\begin{array}{l}\text { International Journal of } \\
\text { Sustainable Energy }\end{array}$ & Life Cycle Assessment & $\begin{array}{l}\text { Comprehensive definition of zero } \\
\text { energy building }\end{array}$ \\
\hline $\begin{array}{l}\text { Tarighaleslami et al. } \\
\text { [43] }\end{array}$ & 2020 & $\begin{array}{l}\text { Journal of Cleaner } \\
\text { Production }\end{array}$ & $\begin{array}{l}\text { Monte Carlo Methods, } \\
\text { Life Cycle Assessment }\end{array}$ & $\begin{array}{l}\text { Assessment for a cheese production } \\
\text { plant }\end{array}$ \\
\hline Vellini et al. [38] & 2020 & $\begin{array}{l}\text { Journal of Cleaner } \\
\text { Production }\end{array}$ & $\begin{array}{l}\text { Cost-Benefit Analysis, } \\
\text { Sensitivity Analysis }\end{array}$ & $\begin{array}{l}\text { Quantification of the economic } \\
\text { burden associated with the } \\
\text { reduction of direct } \mathrm{CO}_{2} \text { emissions }\end{array}$ \\
\hline Wang et al. [153] & 2020 & Energy & $\begin{array}{l}\text { Cost-Benefit Analysis, } \\
\text { Environmental Impact } \\
\text { Assessment }\end{array}$ & $\begin{array}{l}\text { Cost-benefit analysis on different } \\
\text { domestic energy use options }\end{array}$ \\
\hline Wei et al. [154] & 2020 & $\begin{array}{l}\text { China Economic } \\
\text { Review }\end{array}$ & $\begin{array}{c}\text { Preference Evaluation } \\
\text { OR Econometrics, } \\
\text { Quantitative Analysis }\end{array}$ & $\begin{array}{l}\text { Presentation of energy demand } \\
\text { progress in China }\end{array}$ \\
\hline Wen et al. [155] & 2020 & $\begin{array}{l}\text { International Journal of } \\
\text { Electrical Power and } \\
\text { Energy Systems }\end{array}$ & Quantitative Analysis & $\begin{array}{l}\text { Quantitative analysis of the energy } \\
\text { transition in China and future } \\
\text { hypothetical scenarios }\end{array}$ \\
\hline Wiehe et al. [156] & 2020 & $\begin{array}{l}\text { International Journal of } \\
\text { Energy Research }\end{array}$ & $\begin{array}{c}\text { Geographical } \\
\text { Information System }\end{array}$ & $\begin{array}{l}\text { Presentation of a geospatial model } \\
\text { that calculates the potential of } \\
\text { renewable energies and their } \\
\text { influence on society }\end{array}$ \\
\hline Yan et al. [157] & 2020 & IEEE Sensors Journal & Neural Network & $\begin{array}{l}\text { Proposal for an ultrasonic method } \\
\text { for the inspection of gas pipelines }\end{array}$ \\
\hline
\end{tabular}

\section{References}

1. Becchio, C.; Becchio, C.; Delmastro, C.; Fabi, V.; Lombardi, P. The role of nearly-zero energy buildings in the transition towards Post-Carbon Cities. Sustain. Cities Soc. 2016, 27, 324-337. [CrossRef]

2. Bottero, M.; Caprioli, C.; Cotella, G.; Santangelo, M. Sustainable Cities: A Reflection on Potentialities and Limits based on Existing Eco-Districts in Europe. Sustainability 2019, 11, 5794. [CrossRef]

3. European Commission. A Roadmap for Moving to a Competitive Low Carbon Economy in 2050; European Commission: Brussels, Belgium, 2011.

4. United Nations Department of Economic and Social Affairs. The Sustainable Development Goals Report 2016; United Nations Department of Economic and Social Affairs: New York, NY, USA, 2016.

5. European Commission. The European Green Deal; European Commission: Brussels, Belgium, 2019. 
6. Napoli, G.; Barbaro, S.; Giuffrida, S.; Trovato, M.R. The European Green Deal: New Challenges for the Economic Feasibility of Energy Retrofit at District Scale. In New Metropolitan Perspectives; Bevilacqua, C., Calabrò, F., Della Spina, L., Eds.; Springer: Cham, Switzerland, 2021; pp. 1248-1258.

7. International Organization for Standardization. Building and Constructed Assets-Service Life Planning-Part 8: Reference Service Life and Service Life Estimation; ISO 15686-8:2008; International Organization for Standardization: Geneva, Switzerland, 2008.

8. European Commission. Guide to Cost-Benefit Analysis of Investment Projects: Economic Appraisal Tool for Cohesion Policy 2014-2020; European Commission: Brussels, Belgium, 2014.

9. European Commission. Directive 2010/31/UE, Energy Performance of Building Directive Recast (EPBD Recast); European Commission: Brussels, Belgium, 2010.

10. Strantzali, E.; Aravossis, K. Decision making in renewable energy investments: A review. Renew. Sustain. Energy Rev. 2016, 55, 885-898. [CrossRef]

11. Becchio, C.; Bottero, M.; Corgnati, S.; Dell'Anna, F.; Pederiva, G.; Vergerio, G. Proposal for an Integrated Approach to Support Urban Sustainability: The COSIMA Method Applied to Eco-Districts. In Smart and Sustainable Planning for Cities and Regions; Bisello, A., Vettorato, D., Ludlow, D., Baranzelli, C., Eds.; Springer: Cham, Switzerland, 2021; in press.

12. Prestwood, E.; Longhurst, J.; Townsend, I.; Haines, T.; Tsiarapa, E. Facilitating stakeholder dialogues on a carbon neutral city: We need to talk about carbon (and air quality). Air Pollut. XXVI 2018, 501-510. [CrossRef]

13. Laine, J.; Heinonen, J.; Junnila, S. Pathways to Carbon-Neutral Cities Prior to a National Policy. Sustainability 2020, 12, 2445. [CrossRef]

14. Awadh, O. Sustainability and green building rating systems: LEED, BREEAM, GSAS and Estidama critical analysis. J. Build. Eng. 2017, 11, 25-29. [CrossRef]

15. Kaur, H.; Garg, P. Urban sustainability assessment tools: A review. J. Clean. Prod. 2019, 210, 146-158. [CrossRef]

16. Dell'Anna, F.; Bottero, M. Green premium in buildings: Evidence from the real estate market of Singapore. J. Clean. Prod. 2021, 286, 125327. [CrossRef]

17. BRE Global. GreenBook Live: Certified BREEAM Assessments; BRE Global: Hertfordshire, UK, 2015.

18. USGBC U.S. Green Building Council-Green Building Rating System; USGBC U.S.: Washington, DC, USA, 2011.

19. Green Building Council of Australia. Green Star Communities. Guide for Local Governemnt; Green Building Council of Australia: Sydney, Australia, 2012.

20. Japan Sustainable Building Consortium. Comprehensive Assessment System for Built Environment Efficiency (CASBEE); Japan Sustainable Building Consortium: Tokyo, Japan, 2010.

21. BCA. Green Mark Buildings Directory; BCA: Singapore, Singapore, 2005.

22. Yiran, G.A.B.; Ablo, A.D.; Asem, F.E. Urbanisation and domestic energy trends: Analysis of household energy consumption patterns in relation to land-use change in peri-urban Accra, Ghana. Land Use Policy 2020, 99, 105047. [CrossRef]

23. Oudes, D.; Stremke, S. Climate adaptation, urban regeneration and brownfield reclamation: A literature review on landscape quality in large-scale transformation projects. Landsc. Res. 2020, 45, 905-919. [CrossRef]

24. Brunet, C.; Savadogo, O.; Baptiste, P.; Bouchard, M.A.; Rakotoary, J.C.; Ravoninjatovo, A.; Cholez, C.; Gendron, C.; Merveille, N. Impacts Generated by a Large-Scale Solar Photovoltaic Power Plant Can Lead to Conflicts between Sustainable Development Goals: A Review of Key Lessons Learned in Madagascar. Sustainability 2020, 12, 7471. [CrossRef]

25. Raoux, A.; Dambacher, J.M.; Pezy, J.-P.; Mazé, C.; Dauvin, J.-C.; Niquil, N. Assessing cumulative socio-ecological impacts of offshore wind farm development in the Bay of Seine (English Channel). Mar. Policy 2018, 89, 11-20. [CrossRef]

26. Vakulchuk, R.; Overland, I.; Scholten, D. Renewable energy and geopolitics: A review. Renew. Sustain. Energy Rev. 2020, 122, 109547. [CrossRef]

27. Selvakkumaran, S.; Ahlgren, E.O. Review of the use of system dynamics (SD) in scrutinizing local energy transitions. J. Environ. Manag. 2020, 272, 111053. [CrossRef] [PubMed]

28. Gährs, S.; Knoefel, J. Stakeholder demands and regulatory framework for community energy storage with a focus on Germany. Energy Policy 2020, 144, 111678. [CrossRef]

29. Biresselioglu, M.E.; Demir, M.H.; Demirbag-Kaplan, M.; Solak, B. Individuals, collectives, and energy transition: Analysing the motivators and barriers of European decarbonisation. Energy Res. Soc. Sci. 2020, 66, 101493. [CrossRef]

30. Horschig, T.; Thrän, D. Are decisions well supported for the energy transition? A review on modeling approaches for renewable energy policy evaluation. Energy, Sustain. Soc. 2017, 7, 5. [CrossRef]

31. Leontief, W. Input-Output Economics; Oxford University Press: Oxford, UK, 1986; ISBN 0195035275.

32. Burfisher, M.E. Introduction to Computable General Equilibrium Models; Cambridge University Press: Cambridge, UK, 2011; ISBN 9780511975004.

33. Datola, G.; Bottero, M.; De Angelis, E. How Urban Resilience Can Change Cities: A System Dynamics Model Approach. In Lecture Notes in Computer Science; Springer: New York, NY, USA, 2019; pp. 108-122. [CrossRef]

34. Caprioli, C.; Bottero, M.; De Angelis, E. Supporting Policy Design for the Diffusion of Cleaner Technologies: A Spatial Empirical Agent-Based Model. ISPRS Int. J. Geo-Inf. 2020, 9, 581. [CrossRef]

35. Rossi, P.; Lipsey, M.; Freeman, H. Evaluation: A Systematic Approach, 7th ed.; SAGE Publications: Thousand Oaks, CA, USA, 2004.

36. D'Alpaos, C.; Bragolusi, P. Multicriteria prioritization of policy instruments in buildings energy retrofit. Valori Valutazioni 2018, $21,15-25$. 
37. International Organization for Standardization. ISO 15686:2008_Buildings and Constructed Assets—Service-Life Planning-Part 5: Life Cycle Costing. ISO/TC 59/CS 14; International Organization for Standardization: Geneva, Switzerland, 2008.

38. Vellini, M.; Bellocchi, S.; Gambini, M.; Manno, M.; Stilo, T. Impact and costs of proposed scenarios for power sector decarbonization: An Italian case study. J. Clean. Prod. 2020, 123667. [CrossRef]

39. Ameur, A.; Berrada, A.; Loudiyi, K.; Aggour, M. Forecast modeling and performance assessment of solar PV systems. J. Clean. Prod. 2020, 267, 122167. [CrossRef]

40. Dell'Anna, F. Green jobs and energy efficiency as strategies for economic growth and the reduction of environmental impacts. Energy Policy 2020, 112031. [CrossRef]

41. Cucchiella, F.; D'Adamo, I.; Gastaldi, M. A profitability assessment of small-scale photovoltaic systems in an electricity market without subsidies. Energy Convers. Manag. 2016, 129, 62-74. [CrossRef]

42. Ghannadzadeh, A.; Tarighaleslami, A.H. Environmental life cycle assessment of glycerine production: Energy transition from natural gas to biomass. Sustain. Energy Technol. Assess. 2020, 42, 100775. [CrossRef]

43. Tarighaleslami, A.H.; Ghannadzadeh, A.; Atkins, M.J.; Walmsley, M.R. Environmental life cycle assessment for a cheese production plant towards sustainable energy transition: Natural gas to biomass vs. natural gas to geothermal. J. Clean. Prod. 2020, 275, 122999. [CrossRef]

44. Banacloche, S.; Herrera, I.; Lechón, Y. Towards energy transition in Tunisia: Sustainability assessment of a hybrid concentrated solar power and biomass plant. Sci. Total. Environ. 2020, 744, 140729. [CrossRef] [PubMed]

45. Jiang, L.; Xue, B.; Ma, Z.; Yu, L.; Huang, B.; Chen, X. A life-cycle based co-benefits analysis of biomass pellet production in China. Renew. Energy 2020, 154, 445-452. [CrossRef]

46. Cox, B.; Bauer, C.; Beltran, A.M.; Van Vuuren, D.P.; Mutel, C.L. Life cycle environmental and cost comparison of current and future passenger cars under different energy scenarios. Appl. Energy 2020, 269, 115021. [CrossRef]

47. Ghannadzadeh, A. Exergy-aided environmental sustainability assessment of an ethylene dichloride-vinyl chloride production process. Chem. Eng. Res. Des. 2018, 130, 109-128. [CrossRef]

48. Ghannadzadeh, A. Assessment of power generation from natural gas and biomass to enhance environmental sustainability of a polyol ether production process for rigid foam polyurethane synthesis. Renew. Energy 2018, 115, 846-858. [CrossRef]

49. Harajli, H.; Kabakian, V.; El-Baba, J.; Diab, A.; Nassab, C. Commercial-scale hybrid solar photovoltaic-diesel systems in select Arab countries with weak grids: An integrated appraisal. Energy Policy 2020, 137, 111190. [CrossRef]

50. Bottero, M.; D'Alpaos, C.; Dell'Anna, F. Boosting Investments in Buildings Energy Retrofit: The Role of Incentives. In New Metropolitan Perspectives; Bevilacqua, C., Calabro, F., Della Spina, L., Eds.; Springer: Cham, Switzerland, 2019; pp. 593-600. ISBN 9783319921013.

51. Becchio, C.; Bertoncini, M.; Boggio, A.; Bottero, M.; Corgnati, S.P.; Dell'Anna, F. The Impact of Users' Lifestyle in Zero-Energy and Emission Buildings: An Application of Cost-Benefit Analysis. In New Metropolitan Perspectives; Calabrò, F., Della Spina, L., Bevilacqua, C., Eds.; Springer: Cham, Switzerland, 2019; pp. 123-131.

52. Barnes, D.F.; Krutilla, K.; Hyde, W.F. The Urban Household Energy Transition: Social and Environmental Impacts in the Developing World; Routledge: Abingdon, UK, 2005; ISBN 9781936331000.

53. Shterenlikht, A.; Howard, I.C. The CAFE model of fracture-Application to a TMCR steel. Fatigue Fract. Eng. Mater. Struct. 2006, 29, 770-787. [CrossRef]

54. Duke, M.; Ladewig, B.P.; Smart, S.; Rudolph, V.; Da Costa, J.C.D.; Da Costa, J.C.D. Assessment of postcombustion carbon capture technologies for power generation. Front. Chem. Eng. China 2009, 4, 184-195. [CrossRef]

55. Guasco, T.L.; Johnson, M.A.; McCoy, A.B. Unraveling Anharmonic Effects in the Vibrational Predissociation Spectra of H5O2+and Its Deuterated Analogues. J. Phys. Chem. A 2011, 115, 5847-5858. [CrossRef] [PubMed]

56. Arthur, M.D.F.S.; Bond, C.A.; Willson, B. Estimation of elasticities for domestic energy demand in Mozambique. Energy Econ. 2012, 34, 398-409. [CrossRef]

57. Heun, M.K.; De Wit, M. Energy return on (energy) invested (EROI), oil prices, and energy transitions. Energy Policy 2012, 40, 147-158. [CrossRef]

58. Schaede, H.; Von Ahsen, A.; Rinderknecht, S.; Schiereck, D. Electric energy storages-A method for specification, design and assessment. Int. J. Agil. Syst. Manag. 2013, 6, 142. [CrossRef]

59. Eising, J.W.; Van Onna, T.; Alkemade, F. Towards smart grids: Identifying the risks that arise from the integration of energy and transport supply chains. Appl. Energy 2014, 123, 448-455. [CrossRef]

60. Evanno, S.; Weinberger, B. Procédés de méthanisation et gestion des risques industriels. Tech. Sci. Méthodes 2014, 62-73. [CrossRef]

61. King, C.W. Matrix method for comparing system and individual energy return ratios when considering an energy transition. Energy 2014, 72, 254-265. [CrossRef]

62. Nordman, E.E. Energy transitions in Kenya's tea sector: A wind energy assessment. Renew. Energy 2014, 68, 505-514. [CrossRef]

63. Zimmermann, B.M.; Dura, H.; Weil, M. Towards time-resolved LCA of electric vehicles in Germany. Met. Res. Technol. 2014, 111, 169-178. [CrossRef]

64. Bachmann, T.M. Assessing Air Pollutant-Induced, Health-Related External Costs in the Context of Nonmarginal System Changes: A Review. Environ. Sci. Technol. 2015, 49, 9503-9517. [CrossRef] [PubMed]

65. Wesseh, P.K.; Lin, B. Renewable energy technologies as beacon of cleaner production: A real options valuation analysis for Liberia. J. Clean. Prod. 2015, 90, 300-310. [CrossRef] 
66. Zimmermann, B.M.; Dura, H.; Baumann, M.; Weil, M. Prospective time-resolved LCA of fully electric supercap vehicles in Germany. Integr. Environ. Assess. Manag. 2015, 11, 425-434. [CrossRef]

67. Calvert, K. From 'energy geography' to 'energy geographies'. Prog. Hum. Geogr. 2015, 40, 105-125. [CrossRef]

68. Herbert, A.-S.; Azzaro-Pantel, C.; Le Boulch, D. A typology for world electricity mix: Application for inventories in Consequential LCA (CLCA). Sustain. Prod. Consum. 2016, 8, 93-107. [CrossRef]

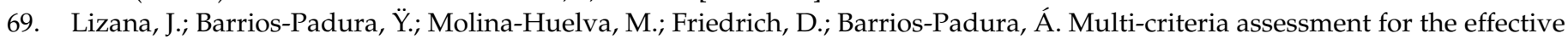
decision management in residential energy retrofitting. Energy Build. 2016, 129, 284-307. [CrossRef]

70. Sager-Klauß, C.V. Energetic Communities: Planning Support for Sustainable Energy Transition in Small-and Medium-Sized Communities; TU Delft: Delft, The Netherlands, 2016; Volume 5, ISBN 9789461866363.

71. Sgouridis, S.; Abdullah, A.; Griffiths, S.; Saygin, D.; Wagner, N.; Gielen, D.; Reinisch, H.; McQueen, D. RE-mapping the UAE's energy transition: An economy-wide assessment of renewable energy options and their policy implications. Renew. Sustain. Energy Rev. 2016, 55, 1166-1180. [CrossRef]

72. Carlier, J.-L.; Chardonnet, C. A high voltage power line: The route with the least environmental and health impact. Public consultation on the plan to rebuild the $400 \mathrm{kV}$ power line between Lille and Arras I Tracé de moindre impact environnemental et sanitaire pour une ligne électrique. Environ. Risques Sante 2017, 16, 292-300. [CrossRef]

73. Kaltenegger, O.; Baikowski, M.; Lingens, J.; Löschel, A. Energy costs in Germany and Europe: An assessment based on a (total real unit) energy cost accounting framework. Energy Policy 2017, 104, 419-430. [CrossRef]

74. Ketzer, D.; Rösch, C.; Haase, M. Assessment of sustainable Grassland biomass potentials for energy supply in Northwest Europe. Biomass-Bioenergy 2017, 100, 39-51. [CrossRef]

75. Kraan, O.; Kramer, G.J.; Van Der Lei, T.; Huppes, G. Modelling the Energy Transition: Towards an Application of Agent Based Modelling to Integrated Assessment Modelling. Adv. Intell. Syst. Comput. 2017, 528, 207-216.

76. Li, F.G.; Trutnevyte, E. Investment appraisal of cost-optimal and near-optimal pathways for the UK electricity sector transition to 2050. Appl. Energy 2017, 189, 89-109. [CrossRef]

77. Loßner, M.; Böttger, D.; Bruckner, T. Economic assessment of virtual power plants in the German energy market-A scenario-based and model-supported analysis. Energy Econ. 2017, 62, 125-138. [CrossRef]

78. Muratori, M.; Ledna, C.; McJeon, H.; Kyle, P.; Patel, P.; Kim, S.H.; Wise, M.; Kheshgi, H.S.; Clarke, L.E.; Edmonds, J. Cost of power or power of cost: A U.S. modeling perspective. Renew. Sustain. Energy Rev. 2017, 77, 861-874. [CrossRef]

79. Rakotoson, V.; Praene, J.P. A life cycle assessment approach to the electricity generation of French overseas territories. J. Clean. Prod. 2017, 168, 755-763. [CrossRef]

80. Scipioni, A.; Manzardo, A.; Ren, R. Hydrogen Economy: Supply Chain, Life Cycle Analysis and Energy Transition for Sustainability; Academic Press: Cambridge, MA, USA, 2017; ISBN 9780128111338.

81. Serp, J.; Poinssot, C.; Bourg, S. Assessment of the Anticipated Environmental Footprint of Future Nuclear Energy Systems. Evidence of the Beneficial Effect of Extensive Recycling. Energies 2017, 10, 1445. [CrossRef]

82. Wan Ahmad, W.N.K.; Rezaei, J.; Sadaghiani, S.; Tavasszy, L.A. Evaluation of the external forces affecting the sustainability of oil and gas supply chain using Best Worst Method. J. Clean. Prod. 2017, 153, 242-252. [CrossRef]

83. Wang, J.; Sun, T.; Deng, S.; Li, K.; Zhao, J.; Gao, L.; Wang, Y. A resilience analysis on energy system: A preliminary case study for solar-assisted CCS. Energy Procedia 2017, 142, 3220-3225. [CrossRef]

84. Danielson, M.; Ekenberg, L.; Komendantova, N. A Multi-Stakeholder Approach to Energy Transition Policy Formation in Jordan; Springer: Cham, Switzerland, 2018; Volume 315, ISBN 9783319928739.

85. Deakin, M.; Reid, A. Smart cities: Under-gridding the sustainability of city-districts as energy efficient-low carbon zones. J. Clean. Prod. 2018, 173, 39-48. [CrossRef]

86. Desthieux, G.; Carneiro, C.; Camponovo, R.; Ineichen, P.; Morello, E.; Boulmier, A.; Abdennadher, N.; Dervey, S.; Ellert, C. Solar Energy Potential Assessment on Rooftops and Facades in Large Built Environments Based on LiDAR Data, Image Processing, and Cloud Computing. Methodological Background, Application, and Validation in Geneva (Solar Cadaster). Front. Built Environ. 2018, 4. [CrossRef]

87. Huang, J.; Xue, Y.; Jiang, C.; Xue, F.; Qian, F. Carbon Market Risk Analysis and Control Part I Framework Design. Dianli Xitong Zidonghua/Automation. Electr. Power Syst. 2018, 42, 11-18. [CrossRef]

88. Li, F.G.; Pye, S. Uncertainty, politics, and technology: Expert perceptions on energy transitions in the United Kingdom. Energy Res. Soc. Sci. 2018, 37, 122-132. [CrossRef]

89. Prol, J.L.; Steininger, K.W. The social profitability of photovoltaics in Germany. Prog. Photovolt. Res. Appl. 2018, 26, 631-641. [CrossRef]

90. Maennel, A.; Kim, H.-G. Comparison of Greenhouse Gas Reduction Potential through Renewable Energy Transition in South Korea and Germany. Energies 2018, 11, 206. [CrossRef]

91. Meschede, H.; Child, M.; Breyer, C. Assessment of sustainable energy system configuration for a small Canary island in 2030. Energy Convers. Manag. 2018, 165, 363-372. [CrossRef]

92. Meylan, G.; Haupt, M.; Duygan, M.; Hellweg, S.; Stauffacher, M. Linking energy scenarios and waste storylines for prospective environmental assessment of waste management systems. Waste Manag. 2018, 81, 11-21. [CrossRef]

93. Mullally, G.; Dunphy, N.; O'Connor, P. Participative environmental policy integration in the Irish energy sector. Environ. Sci. Policy 2018, 83, 71-78. [CrossRef] 
94. Shmelev, S.E.; Shmeleva, I.A. Global urban sustainability assessment: A multidimensional approach. Sustain. Dev. 2018, 26, 904-920. [CrossRef]

95. Skoczkowski, T.; Bielecki, S.; Węglarz, A.; Włodarczak, M.; Gutowski, P. Impact assessment of climate policy on Poland's power sector. Mitig. Adapt. Strat. Glob. Chang. 2018, 23, 1303-1349. [CrossRef] [PubMed]

96. Moghadam, S.T.; Toniolo, J.; Mutani, G.; Lombardi, P. A GIS-statistical approach for assessing built environment energy use at urban scale. Sustain. Cities Soc. 2018, 37, 70-84. [CrossRef]

97. Tronchin, L.; Manfren, M.; James, P.A. Linking design and operation performance analysis through model calibration: Parametric assessment on a Passive House building. Energy 2018, 165, 26-40. [CrossRef]

98. Walker, S.; Labeodan, T.; Boxem, G.; Maassen, W.; Zeiler, W. An assessment methodology of sustainable energy transition scenarios for realizing energy neutral neighborhoods. Appl. Energy 2018, 228, 2346-2360. [CrossRef]

99. Wen, Y.; Cai, B.; Xue, Y.; Wang, S.; Chen, Z.; Zhu, J.; Jiang, D.; Yue, Z. Assessment of Power System Low-carbon Transition Pathways Based on China's Energy Revolution Strategy. Energy Procedia 2018, 152, 1039-1044. [CrossRef]

100. Zaman, R.; Brudermann, T.; Kumar, S.; Islam, N. A multi-criteria analysis of coal-based power generation in Bangladesh. Energy Policy 2018, 116, 182-192. [CrossRef]

101. Zeyringer, M.; Fais, B.; Keppo, I.; Price, J. The potential of marine energy technologies in the UK-Evaluation from a systems perspective. Renew. Energy 2018, 115, 1281-1293. [CrossRef]

102. Zimmermann, M.; Pye, S. Inequality in energy and climate policies: Assessing distributional impact consideration in UK policy appraisal. Energy Policy 2018, 123, 594-601. [CrossRef]

103. Bódis, K.; Kougias, I.; Jäger-Waldau, A.; Taylor, N.; Szabó, S. A high-resolution geospatial assessment of the rooftop solar photovoltaic potential in the European Union. Renew. Sustain. Energy Rev. 2019, 114, 114. [CrossRef]

104. Böing, F.; Regett, A. Hourly $\mathrm{CO}_{2}$ Emission Factors and Marginal Costs of Energy Carriers in Future Multi-Energy Systems. Energies 2019, 12, 2260. [CrossRef]

105. Burnley, S.J. A life cycle assessment of energy from waste and recycling in a post-carbon future. Detritus 2018 , 5, 150-162. [CrossRef]

106. Camargo, L.R.; Wuth, J.; Biberacher, M.; Dorner, W. A spatially explicit assessment of middle and low voltage grid requirements in Bavaria until 2050. GeoScape 2019, 13, 88-97. [CrossRef]

107. Cavalcanti, E.J.; Carvalho, M.; Azevedo, J.L.B. Exergoenvironmental results of a eucalyptus biomass-fired power plant. Energy 2019, 189, 116188. [CrossRef]

108. Coroiu, M. Energy efficiency holistic approach for new energy business model towards 2030. In Proceedings of the 2019 8th International Conference on Modern Power Systems (MPS), Cluj Napoca, Romania, 21-23 May 2019; pp. 1-8.

109. Correa-Florez, C.; Michiorri, A.; Kariniotakis, G. Comparative Analysis of Adjustable Robust Optimization Alternatives for the Participation of Aggregated Residential Prosumers in Electricity Markets. Energies 2019, 12, 1019. [CrossRef]

110. Costantini, V.; Crespi, F.; Paglialunga, E. Capital-energy substitutability in manufacturing sectors: Methodological and policy implications. Eurasian Bus. Rev. 2018, 9, 157-182. [CrossRef]

111. Drouilles, J.; Aguacil, S.; Hoxha, E.; Jusselme, T.; Lufkin, S.; Rey, E. Environmental impact assessment of Swiss residential archetypes: A comparison of construction and mobility scenarios. Energy Effic. 2019, 12, 1661-1689. [CrossRef]

112. Ghannadzadeh, A.; Meymivand, A. Environmental sustainability assessment of an ethylene oxide production process through Cumulative Exergy Demand and ReCiPe. Clean Technol. Environ. Policy 2019, 21, 1765-1777. [CrossRef]

113. Ghannadzadeh, A.; Tarighaleslami, A.H. Exergetic environmental sustainability assessment supported by Monte Carlo simulations: A case study of a chlorine production process. Environ. Prog. Sustain. Energy 2019, 38. [CrossRef]

114. Jenniches, S.; Worrell, E. Regional economic and environmental impacts of renewable energy developments: Solar PV in the Aachen Region. Energy Sustain. Dev. 2019, 48, 11-24. [CrossRef]

115. Jin, Y.; Behrens, P.; Tukker, A.; Scherer, L. Water use of electricity technologies: A global meta-analysis. Renew. Sustain. Energy Rev. 2019, 115, 109391. [CrossRef]

116. Leporini, M.; Marchetti, B.; Corvaro, F.; Polonara, F. Reconversion of offshore oil and gas platforms into renewable energy sites production: Assessment of different scenarios. Renew. Energy 2019, 135, 1121-1132. [CrossRef]

117. Marcucci, A.; Panos, E.; Kypreos, S.; Fragkos, P. Probabilistic assessment of realizing the $1.5^{\circ} \mathrm{C}$ climate target. Appl. Energy 2019, 239, 239-251. [CrossRef]

118. Markov, K.K.; Rajaković, N. Multi-energy microgrids with ecotourism purposes: The impact of the power market and the connection line. Energy Convers. Manag. 2019, 196, 1105-1112. [CrossRef]

119. Mohajeri, N.; Perera, A.; Coccolo, S.; Mosca, L.; Le Guen, M.; Scartezzini, J.-L. Integrating urban form and distributed energy systems: Assessment of sustainable development scenarios for a Swiss village to 2050. Renew. Energy 2019, 143, 810-826. [CrossRef]

120. Nitsch, F.; Turkovska, O.; Schmidt, J. Observation-based estimates of land availability for wind power: A case study for Czechia. Energy, Sustain. Soc. 2019, 9, 1-13. [CrossRef]

121. Pedinotti-Castelle, M.; Astudillo, M.F.; Pineau, P.-O.; Amor, B. Is the environmental opportunity of retrofitting the residential sector worth the life cycle cost? A consequential assessment of a typical house in Quebec. Renew. Sustain. Energy Rev. 2019, 101, 428-439. [CrossRef]

122. Selvakkumaran, S.; Ahlgren, E.O. Determining the factors of household energy transitions: A multi-domain study. Technol. Soc. 2019, 57, 54-75. [CrossRef] 
123. Stremke, S.; Schöbel, S. Research through design for energy transition: Two case studies in Germany and The Netherlands. Smart Sustain. Built Environ. 2019, 8, 16-33. [CrossRef]

124. Thonemann, N.; Maga, D. Life Cycle Assessment of German Energy Scenarios; Springer: Cham, Switzerland, 2018 ; pp. 165-175.

125. Watari, T.; McLellan, B.C.; Giurco, D.; Dominish, E.; Yamasue, E.; Nansai, K. Total material requirement for the global energy transition to 2050: A focus on transport and electricity. Resour. Conserv. Recycl. 2019, 148, 91-103. [CrossRef]

126. Yang, D.; Huang, J.; Hu, X.; Guo, H.; Xie, D. Breakdown of energy transfer gap laws revealed by full-dimensional quantum scattering between HF molecules. Nat. Commun. 2019, 10, 1-6. [CrossRef]

127. Yang, X.; Cai, B.; Xue, Y.; Zhang, J.; Zhao, Y.; Hu, R. Quantitative Assessment of Clean Transition of GenCo Considering Other Participants' Generation Investment. Energy Procedia 2019, 156, 23-27. [CrossRef]

128. Yu, H.-H.; Chang, K.-H.; Hsu, H.-W.; Cuckler, R. A Monte Carlo simulation-based decision support system for reliability analysis of Taiwan's power system: Framework and empirical study. Energy 2019, 178, 252-262. [CrossRef]

129. Albers, A.; Collet, P.; Benoist, A.; Hélias, A. Back to the future: Dynamic full carbon accounting applied to prospective bioenergy scenarios. Int. J. Life Cycle Assess. 2019, 25, 1242-1258. [CrossRef]

130. Albers, A.; Avadí, A.; Benoist, A.; Collet, P.; Hélias, A. Modelling dynamic soil organic carbon flows of annual and perennial energy crops to inform energy-transport policy scenarios in France. Sci. Total. Environ. 2020, 718, 135278. [CrossRef]

131. Atkins, E. Contesting the 'greening' of hydropower in the Brazilian Amazon. Polit. Geogr. 2020, 80, 102179. [CrossRef]

132. Braunholtz-Speight, T.; Sharmina, M.; Manderson, E.; McLachlan, C.; Hannon, M.; Hardy, J.; Mander, S. Business models and financial characteristics of community energy in the UK. Nat. Energy 2020, 5, 169-177. [CrossRef]

133. Dean, M.; Blackford, J.; Connelly, D.; Hines, R. Insights and guidance for offshore $\mathrm{CO}_{2}$ storage monitoring based on the QICS, ETI MMV, and STEMM-CCS projects. Int. J. Greenh. Gas Control. 2020, 100, 103120. [CrossRef]

134. Höfer, T.; Madlener, R. A participatory stakeholder process for evaluating sustainable energy transition scenarios. Energy Policy 2020, 139, 111277. [CrossRef]

135. Hu, C.; Huang, J.; Xue, Y.; Li, T.; Song, X.; Lai, Y. Monetary Value Evaluation for Carbon Emission Reduction Benefit of Energy Transition. Dianli Xitong Zidonghua/Autom. Electr. Power Syst. 2020, 44, 29-34. [CrossRef]

136. Kim, P.; Kim, J.; Yim, M.-S. How deliberation changes public opinions on nuclear energy: South Korea's deliberation on closing nuclear reactors. Appl. Energy 2020, 270, 115094. [CrossRef]

137. Kokkinos, K.; Karayannis, V.; Moustakas, K. Circular bio-economy via energy transition supported by Fuzzy Cognitive Map modeling towards sustainable low-carbon environment. Sci. Total. Environ. 2020, 721, 137754. [CrossRef] [PubMed]

138. Middelhauve, L.; Santeccia, A.; Girardin, L.; Margni, M.; Maréchal, F. Key performance indicators for decision making in building energy systems. In Proceedings of the ECOS 2020-Proceedings of the 33rd International Conference on Efficiency, Cost, Optimization, Simulation and Environmental Impact of Energy Systems, Osaka, Japan, 29 June-3 July 2020; pp. 401-412.

139. Miranda, M.M.; Raymond, J.; Dezayes, C. Uncertainty and Risk Evaluation of Deep Geothermal Energy Source for Heat Production and Electricity Generation in Remote Northern Regions. Energies 2020, 13, 4221. [CrossRef]

140. Muñoz, I.; Hernandez, P.; Pérez-Iribarren, E.; Pedrero, J.; Arrizabalaga, E.; Hermoso, N. Methodology for integrated modelling and impact assessment of city energy system scenarios. Energy Strat. Rev. 2020, 32, 100553. [CrossRef]

141. Nechifor, V.; Calzadilla, A.; Bleischwitz, R.; Winning, M.; Tian, X.; Usubiaga, A. Steel in a circular economy: Global implications of a green shift in China. World Dev. 2020, 127, 104775. [CrossRef]

142. Paltsev, S. Projecting Energy and Climate for the 21st Century. Econ. Energy Environ. Policy 2020, 9, 43-62. [CrossRef]

143. Partidário, P.; Aguiar, R.; Martins, P.; Rangel, C.M.; Cabrita, I. The hydrogen roadmap in the Portuguese energy systemDeveloping the P2G case. Int. J. Hydrog. Energy 2019, 45, 25646-25657. [CrossRef]

144. Patouillard, L.; Lorne, D.; Collet, P.; Bulle, C.; Margni, M. Prioritizing regionalization to enhance interpretation in consequential life cycle assessment: Application to alternative transportation scenarios using partial equilibrium economic modeling. Int. J. Life Cycle Assess. 2020, 25, 2325-2341. [CrossRef]

145. Raugei, M.; Peluso, A.; Leccisi, E.; Fthenakis, V.M. Life-Cycle Carbon Emissions and Energy Return on Investment for 80\% Domestic Renewable Electricity with Battery Storage in California (U.S.A.). Energies 2020, 13, 3934. [CrossRef]

146. Rohe, S. The regional facet of a global innovation system: Exploring the spatiality of resource formation in the value chain for onshore wind energy. Environ. Innov. Soc. Transitions 2020, 36, 331-344. [CrossRef]

147. Sareen, S.; Grandin, J. European green capitals: Branding, spatial dislocation or catalysts for change? Geogr. Ann. Ser. B Hum. Geogr. 2019, 102, 101-117. [CrossRef]

148. Saretta, E.; Caputo, P.; Frontini, F. An integrated 3D GIS-based method for estimating the urban potential of BIPV retrofit of façades. Sustain. Cities Soc. 2020, 62, 102410. [CrossRef]

149. Seck, G.S.; Hache, E.; Bonnet, C.; Simoën, M.; Carcanague, S. Copper at the crossroads: Assessment of the interactions between low-carbon energy transition and supply limitations. Resour. Conserv. Recycl. 2020, 163, 105072. [CrossRef] [PubMed]

150. Sharma, T.; Gallachóir, B.Ó.; Rogan, F. A new hybrid approach for evaluating technology risks and opportunities in the energy transition in Ireland. Environ. Innov. Soc. Transit. 2020, 35, 429-444. [CrossRef]

151. Shaw-Williams, D.; Susilawati, C. A techno-economic evaluation of Virtual Net Metering for the Australian community housing sector. Appl. Energy 2020, 261, 114271. [CrossRef]

152. Taherahmadi, J.; Noorollahi, Y.; Panahi, M. Toward comprehensive zero energy building definitions: A literature review and recommendations. Int. J. Sustain. Energy 2020, 1-29. [CrossRef] 
153. Wang, Q.; Lin, J.; Zhou, K.; Fan, J.; Kwan, M.-P. Does urbanization lead to less residential energy consumption? A comparative study of 136 countries. Energy 2020, 202, 117765. [CrossRef]

154. Wei, C.; Löschel, A.; Managi, S. Recent advances in energy demand research in China. China Econ. Rev. 2020, 63, 101517. [CrossRef]

155. Wen, Y.; Cai, B.; Yang, X.; Xue, Y. Quantitative analysis of China's Low-Carbon energy transition. Int. J. Electr. Power Energy Syst. 2020, 119, 105854. [CrossRef]

156. Wiehe, J.; Thiele, J.; Walter, A.; Hashemifarzad, A.; Hingst, J.Z.; Von Haaren, C. Nothing to regret: Reconciling renewable energies with human wellbeing and nature in the German Energy Transition. Int. J. Energy Res. 2021, 45, 745-758. [CrossRef]

157. Yan, Y.; Liu, D.; Gao, B.; Tian, G.; Cai, Z.C. A Deep Learning-Based Ultrasonic Pattern Recognition Method for Inspecting Girth Weld Cracking of Gas Pipeline. IEEE Sensors J. 2020, 20, 7997-8006. [CrossRef] 